\title{
Geologia e características do fluido mineralizador dos alvos auríferos Jerimum de Cima e Babi, campo mineralizado do Cuiú-Cuiú, Província Aurífera do Tapajós, Cráton Amazônico, com base em estudos de inclusões fluidas e de isótopos estáveis Geology and characteristics of the mineralizing fluid in the Jerimum de Cima and Babi gold prospects, Cuiú-Cuiú goldfield, Tapajós Gold Province, Amazonian Craton, a fluid inclusion and stable isotope study
}

\author{
Carlos Alberto dos Santos Silva Júniorl, Evandro Luiz Klein', "l \\ Universidade Federal do Pará. Belém, Pará, Brasil \\ "Companhia de Pesquisa de Recursos Minerais. Brasília, Distrito Federal, Brasil
}

\begin{abstract}
Resumo: Os alvos auríferos Jerimum de Cima e Babi estão localizados no campo mineralizado do Cuiú-Cuiú, Província Aurífera do Tapajós, Cráton Amazônico. Jerimum de Cima é moderadamente mineralizado, enquanto no alvo Babi a mineralização é incipiente (não econômica). O estudo petrográfico definiu tonalitos, monzogranitos e granodioritos como rochas hospedeiras nos dois alvos. Sericitização, silicificação, sulfetação, cloritização e carbonatação ocorrem nos dois alvos, na forma fissural e disseminada (pervasiva), e os maiores teores de ouro estão associados com maiores concentrações de sulfetos. Inclusões fluidas (IF) aquosas, aquocarbônicas e carbônicas foram classificadas. As IF aquocarbônicas, presentes apenas em Jerimum de Cima, representam o provável fluido mineralizador, indicam imiscibilidade de fluidos (separação de fases) e possível mistura tardia com fluidos mais frios. Estudos de isótopos estáveis em minerais de veios e de zonas de alteração indicam temperaturas de precipitação dos minerais entre 305 e $330^{\circ} \mathrm{C}$ e entre 108 e $205^{\circ} \mathrm{C}$. Também sugerem fontes magmáticas e meteóricas para os fluidos. Os dados obtidos são compatíveis com depósito magmático-hidrotermal (relacionado à intrusão), com mistura de fluido magmático e meteórico. A ausência de $\mathrm{CO}_{2}$ no alvo Babi, assumindo que o aprisionamento do fluido tenha sido tardio em relação à evolução hidrotermal do sistema, pode explicar a fraca mineralização.
\end{abstract}

Palavras-chave: Tapajós. Pressão. Temperatura. Fonte do fluido. Metalogênese.

\begin{abstract}
The Jerimum de Cima and Babi gold prospects are located in the Cuiú-Cuiú goldfield, Tapajós Gold Province, Amazonian Craton. Jerimum de Cima bears moderate mineralization, whereas Babi is only weakly mineralized (not economic). The petrographic investigation defined tonalite, granodiorite and monzogranite as the host rocks in both targets. Sericitization, silicification, sulfidation, chloritization and carbonatization occur in both prospects, as fissure-filling and disseminated alteration. Aqueous, aqueous-carbonic and carbonic fluid inclusions (FI) have been identified. The aqueous-carbonic FI occur only at Jerimum de Cima and likely represent the mineralizing fluid. These FI were produced by fluid immiscibility (phase separation) and, possibly, were mixed with late, colder aqueous fluids. Stable isotopes analyses of hydrothermal minerals present in veins and disseminated alteration indicate mineral precipitation between 305 and $330^{\circ} \mathrm{C}$ and between 108 and $205^{\circ} \mathrm{C}$, and suggest magmatic and meteoric sources for the fluids. As a whole, our data are compatible with magmatic-hydrothermal gold systems (intrusion-related), and with mixing of magmatic and meteoric fluids. The lack of $\mathrm{CO}_{2}$ at Babi may have been caused by the late timing of alteration, when compared with Jerimum de Cima, and might also explain the weak mineralization at Babi.
\end{abstract}

Keywords:Tapajós. Pressure. Temperature. Source fluid. Metallogeny.

SILVA JÚNIOR, C. A. S. \& E. L. KLEIN, 2016. Geologia e características do fluido mineralizador dos alvos auríferos Jerimum de Cima e Babi, campo mineralizado do Cuiú-Cuiú, Província Aurífera do Tapajós, Cráton Amazônico, com base em estudos de inclusões fluidas e de isótopos estáveis. Boletim do Museu Paraense Emílio Goeldi. Ciências Naturais 10(2): 199-230.

Autor para correspondência: Carlos Alberto dos Santos Silva Júnior. Universidade Federal do Pará. Instituto de Geociências. Programa de Pós-Graduação em Geologia e Geoquímica. Rua Augusto Corrêa, 1 - Guamá. Belém, PA, Brasil. CEP 66075-110 (carlosalbertjr@gmail.com). Recebido em 29/06/2015

Aprovado em 22/02/2016

Responsabilidade editorial: Mário Augusto G. Jardim

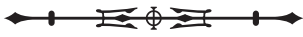




\section{INTRODUÇÃO}

O campo mineralizado do Cuiú-Cuiú, localizado na porção central da Província Aurífera do Tapajós (PAT), porção centro-sul do Cráton Amazônico (Figura 1), é historicamente uma das mais importantes áreas de atividade garimpeira dessa província (produção histórica não oficial de 46-62 t Au, Magellan Minerals Ltd. 2011). Mais recentemente, tem sido alvo de exploração por parte de companhias de mineração, sendo que dois depósitos, Central e Moreira Gomes, foram descobertos (recursos de 40,3 t Au, Magellan Minerals Ltd. 2011), além de diversos alvos ou prospectos, como Pau da Merenda, Ivo, Jerimum de Cima, Jerimum de Baixo, Babi e Guarim.

Estudos anteriores nesses depósitos e alvos, baseados em inclusões fluidas e isótopos estáveis, levaram à interpretação dos mesmos como depósitos

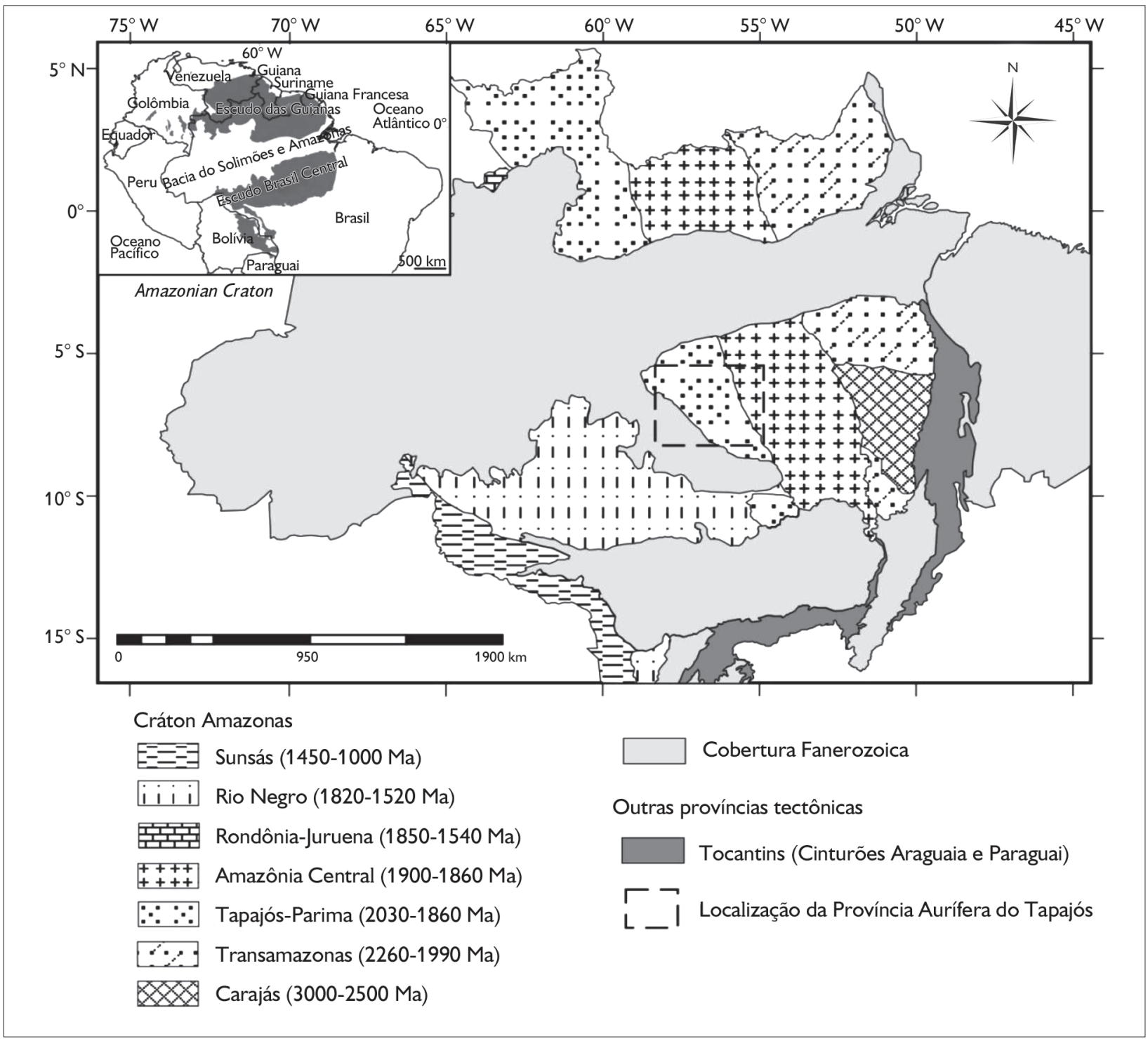

Figura 1. Localização da Província Aurífera do Tapajós (polígono tracejado) em relação às províncias geocronológicas do Cráton Amazônico (modificado de Vasquez et al., 2008).

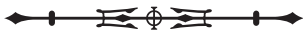


orogênicos (Klein et al., 2001; Coutinho, 2008), ou magmáticos hidrotermais, provavelmente relacionados a intrusões graníticas (Araújo, 2014; Assunção \& Klein, 2014; Silva Júnior et al., 2015). É também relevante, o fato de o alvo Babi não ser mineralizado economicamente, mas apresentar, segundo Magellan Minerals Ltd. (2011), características geológicas similares às dos alvos mineralizados e depósitos.

Portanto, em uma tentativa de entender essa diferença fundamental do alvo Babi, e como forma de contribuir com a compreensão metalogenética do campo mineralizado do Cuiú-Cuiú em geral, este trabalho buscou fazer um estudo comparativo entre os alvos Jerimum de Cima e Babi, no que concerne às características físico-químicas dos fluidos que provocaram a alteração hidrotermal nesses alvos e que permitiram mineralização em Jerimum de Cima (e outros alvos/depósitos do campo), o que ocorreu fracamente no alvo Babi (não mineralizado ou apenas incipientemente mineralizado - não econômico).

\section{CONTEXTO GEOLÓGICO}

A Província Aurífera do Tapajós está inserida na Província Tapajós-Parima, conforme definição de Santos et al. (2000) (Figura 1). Quatro domínios foram definidos por Santos et al. (2001) para essa província: localizados ao norte da Bacia do Amazonas, os domínios Parima e Uaimiri; e localizados ao sul da Bacia, os domínios Tapajós e Alta Floresta. Rochas plutônicas e vulcânicas cálcico-alcalinas e alcalinas paleoproterozoicas compõem dominantemente a província. Em termos evolutivos, Santos et al. (2004) propuseram a existência de cinco arcos magmáticos para o Domínio Tapajós, formados durante duas orogêneses. Vasquez et al. (2008), por falta de dados que comprovassem a existência de tantos arcos magmáticos, sugeriram a existência de um único arco magmático, com expressivo magmatismo pós-colisional associado, seguido da formação de riftes continentais paleoproterozoicos em eventos tafrogênicos. Concluíram, assim, que o Domínio Tapajós (Figura 2) é representado por associações tectônicas de um orógeno orosiriano originado pela colisão de um arco (arco de ilhas Cuiú-Cuiú) a um continente durante a orogênese Cuiú-Cuiú. Este arco é representado pelo Grupo Jacareacanga e pelo Complexo Cuiú-Cuiú, sendo a primeira constituída por sucessões siliciclásticas e químicas (turbiditos), com subordinado vulcanismo máfico-ultramáfico e basaltos de fundo oceânico, depositada entre 2,1 e 2,01 Ga e metamorfizada na fácies xisto verde a epidoto-anfibolito (Vasquez et al., 2008). Os ortognaisses e granitoides orosirianos (2033 \pm 7 a 2005 \pm 7 Ma; Santos et al., 2001) do Complexo Cuiú-Cuiú representam os granitoides de arco ilha com deformação dúctil e metamorfismo relacionados a uma fase colisional, que teria ocorrido por volta de 2,0 Ga. Ainda associados a essa fase de arco, estariam incluídas as rochas vulcânicas félsicas e piroclásticas da Formação Comandante Arara (2012 \pm 2 Ma a $2020 \pm 2$ Ma; Vasquez et al., 2013) e as rochas vulcânicas cálcico-alcalinas de alto Ka shoshoníticas da Formação Vila Riozinho (2000 \pm 4 Ma a $1998 \pm 3$ Ma; Lamarão et al., 2002). Após a suposta colisão, foram instaladas zonas de cisalhamento transcorrentes de direção NW-SE, que representam a estruturação principal do Domínio Tapajós, ao longo das quais se posicionaram os granitoides tardiorogênicos da Suíte Intrusiva Creporizão (1997 \pm 3 Ma a $1957 \pm 6$ Ma; Vasquez et al., 2000; Santos et al., 2001; Silva Júnior et al., 2015). De acordo com Santos et al. (2004), esses granitoides estariam associados a magmatismo de arco continental e não a uma colisão, em razão da ausência de outros elementos típicos de ambientes colisionais, como leucogranitos peraluminosos, paragnaisses e deformação compressiva.

De acordo com Vasquez et al.(2008), e após um período de 40 a 50 Ma sem litogênese conhecida, os granitoides cálcico-alcalinos das suítes intrusivas Tropas (1907 \pm 9 Ma a $1892 \pm 6$ Ma; Santos et al., 2004) e Parauari (1883 \pm 2 Ma a $1879 \pm 11$ Ma; Santos et al., 2001; Silva Júnior et al., 2015) foram relacionados a uma evolução atribuída à extensão pós-colisional (estágio pós-orogênico), com mistura de magmas mantélicos e crosta continental.

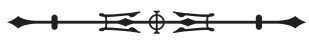




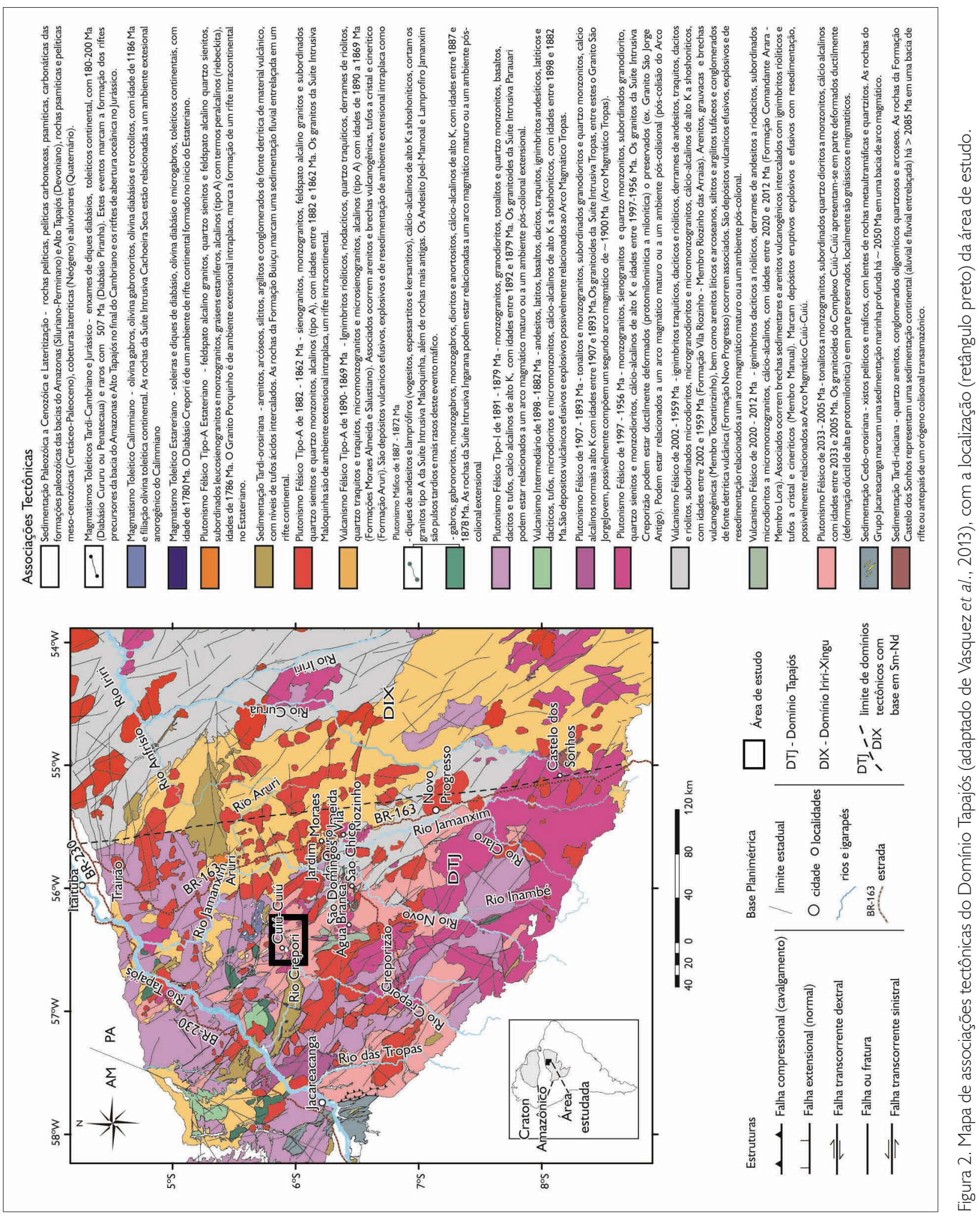


Vários corpos de rochas básicas intrusivas e de idades similares são associados a essa fase. A Suíte Intrusiva Maloquinha, entre outros granitoides similares, as rochas vulcânicas félsicas e piroclásticas do Grupo Iriri e a Formação Moraes Almeida foram formadas por magmatismo de natureza alcalina tipo-A (1890 $\pm 6 \mathrm{Ma}$ a $1870 \pm 8$ Ma; Vasquez et al., 1999; Santos et al., 2001; Lamarão et al., 2002), possivelmente associados a uma um rifte continental (Vasquez et al., 2008) e ao desenvolvimento de uma Silicic Large Igneous Province (SLIP) (Klein et al., 2012). A essa fase se associa a Formação Novo Progresso (Ferreira et al., 2004), siliciclástica e continental. Completando a sequência estratigráfica da PAT, ocorre a cobertura sedimentar fanerozoica originada pela implantação dos riftes continentais, representada pela Formação Buiuçu. Esta formação é constituída por sucessões epiclásticas, com contribuição vulcanoclástica e localmente piroclástica, e foi seccionada por diques e soleiras de diabásio.

\section{GEOLOGIA DO CAMPO MINERALIZADO DO CUIÚ-CUIÚ}

Os depósitos e prospectos do campo mineralizado do Cuiú-Cuiú estão associados a granitoides grossos, localmente porfiríticos, que em mapas anteriores eram atribuídos ao Complexo Cuiú-Cuiú (Bahia \& Quadros, 2000; Klein et al., 2001). Essas rochas são intensamente cortadas por diques andesíticos de granulação fina, e diques aplíticos e pegmatíticos. Contudo, mapeamento geológico recente (Moura et al., 2014) e os dados geocronológicos obtidos por Silva Júnior et al. (2015) para granitoides hospedeiros nos depósitos Central e Moreira Gomes indicam que as rochas datadas se relacionam, respectivamente, às suítes intrusivas Parauari e Creporizão (Figura 3).

Em termos estruturais, são identificados dois sistemas de falhas regionais (NW-SE - trend Tocantinzinho, segundo Magellan Minerals Ltd., 2011). Um está localizado ao norte e outro ao sul da área que concentra os depósitos e prospectos do campo mineralizado do Cuiú-Cuiú. Esses

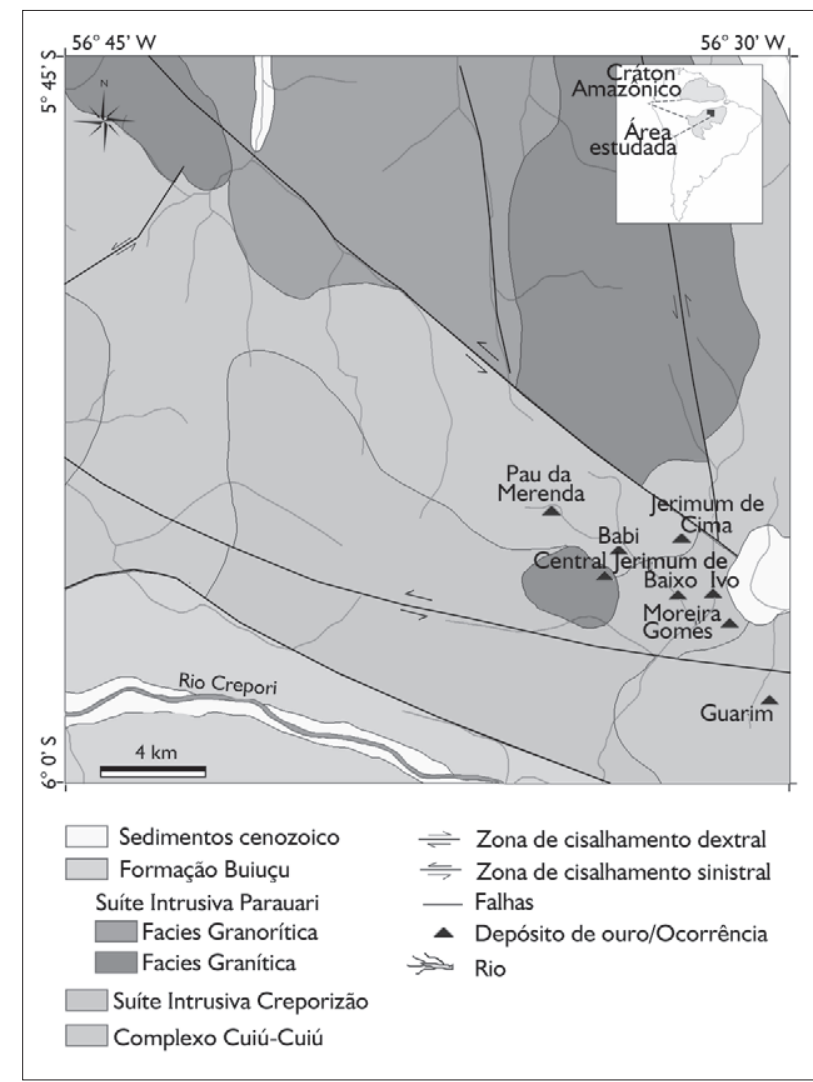

Figura 3. Mapa geológico simplificado da região do Cuiú-Cuiú, com localização dos depósitos e prospectos (adaptado de Moura et al., 2014).

sistemas são parte do megassistema de falhas transcorrentes de direção NW-SE da PAT, conforme definição de Santos \& Coutinho (2008). De acordo com Magellan Minerals Ltd. (2011), a maioria das estruturas hospedeiras dos depósitos auríferos estaria relacionada com o movimento diferencial entre as duas falhas regionais. Ao longo desse trend, estão localizados muitos dos depósitos de ouro mais importantes e garimpos na parte centro-norte da Província Aurífera do Tapajós (por exemplo, São Jorge, Palito, Tocantinzinho, Mamoal, Bom Jardim e Cuiú-Cuiú).

\section{MATERIAIS E MÉTODOS}

Para a realização deste estudo, foram utilizados testemunhos de furos de sondagem, incluindo rochas pouco ou muito alteradas hidrotermalmente, mineralizadas ou não. 
A partir da descrição macroscópica dos testemunhos de sondagem, foram selecionadas 35 amostras para convecção de lâminas polidas para o estudo petrográfico sob a luz transmitida, refletida e por microscopia eletrônica de varredura (MEV). Microscopia eletrônica de varredura acoplada a sistema de dispersão de energia (MEV-EDS) foi realizada no equipamento de marca LEO (modelo 1430) no laboratório (LabMEV) pertencente ao Instituto de Geociências da Universidade Federal do Pará (UFPA), com o objetivo de auxiliar na caracterização de minerais não identificados na petrografia convencional.

Estudo do sistema de fluidos via inclusões fluidas (petrografia, microtermometria) foi desenvolvido nos laboratórios de petrografia e de microtermometria do grupo de Metalogênese da UFPA. O estudo foi realizado em dez seções bipolidas, das quais sete forneceram inclusões de tamanho adequado para análise. Essas seções foram confeccionadas em veios de quartzo mineralizados e em zonas de alteração hidrotermal. Este trabalho foi dividido em duas partes: 1) estudo petrográfico das inclusões fluidas em microscópio petrográfico de luz refletida, com base em critérios genéticos, morfológicos, número de fases, forma de ocorrência, relação temporal, posição no grão, percentual de cada fase e natureza dos fluidos (por exemplo, Roedder, 1984); 2) análises microtermométricas de resfriamento e aquecimento para a determinação das temperaturas de mudanças de fase utilizadas em estimativas de densidade, composição, salinidade e condições de Pressão e Temperatura (P-T) de aprisionamento dos fluidos. A microtermometria foi efetuada em equipamento Linkam TH600, adaptado ao microscópio petrográfico. A calibração do equipamento foi efetuada diariamente com padrões sintéticos de inclusões fluidas, contendo água e $\mathrm{CO}_{2}$ puros. A precisão das medidas é estimada em $\pm 0,5^{\circ} \mathrm{C}$, para temperaturas inferiores a $-20^{\circ} \mathrm{C}$; $\pm 0,3^{\circ} \mathrm{C}$, para o intervalo entre -20 e $40^{\circ} \mathrm{C}$; e $\pm 3^{\circ} \mathrm{C}$, para temperaturas superiores a $40^{\circ} \mathrm{C}$. Os cálculos de salinidade, densidade e isócoras foram realizados com auxilio do programa FLINCOR (Brown, 1989), utilizando as equações de Brown \& Lamb (1986), Bowers \& Helgeson (1983) e Collins (1979).
As análises de isótopos de oxigênio, carbono e enxofre foram efetuadas em concentrados de minerais hidrotermais de zonas hidrotermais da rocha hospedeira e de veios, como quartzo, calcita, sericita, clorita, pirita e esfalerita. Isótopos de oxigênio e carbono foram analisados no Laboratório de Isótopos Estáveis da Universidade Federal de Pernambuco (LABISE-UFPE), usando espectrômetro de massa Thermo Delta $V$ Advantage, utilizando a linha de extração a laser para oxigênio. Para as determinações da composição isotópica de carbono e oxigênio em calcita, o $\mathrm{CO}_{2}$ foi extraído em uma linha de vácuo, após reação com $\mathrm{H}_{3} \mathrm{PO}_{4}$, a $25^{\circ} \mathrm{C}$. $\mathrm{O}$ $\mathrm{CO}_{2}$ extraído foi purificado criogenicamente e a análise de padrão interno (BSC) indica precisão de 0,1\%。 e 0,2\%。 para carbono e oxigênio, respectivamente. Para a análise de isótopos de oxigênio em quartzo e clorita, foi utilizado sistema a laser, com liberação do oxigênio por reação com $\mathrm{BrF}_{5}$ e conversão para $\mathrm{CO}_{2}$ por reação com grafite quente. Os dados brutos foram corrigidos segundo procedimentos descritos em Valley et al. (1995) e a precisão é de 0,1\%o. Os resultados são apresentados na notação delta. Isótopos de enxofre foram analisados no Laboratório de Isótopos Estáveis (LAIS) da Universidade de Brasília, usando a técnica EA-IRMS (Elemental Analysis - Isotope Ratio Mass Spectrometry), com analisador elementar Flash EA e espectrômetro de massa Thermo Fisher MAT 253. Os sulfetos foram depositados em pequenas cápsulas de estanho e colocados em forno com temperatura de 1080 ${ }^{\circ} \mathrm{C}$, onde, por combustão, foram convertidos em $\mathrm{SO}_{2}$, que é carreado em fluxo de hélio e reduzido em contato com fios de cobre de elevada pureza. $\mathrm{OSO}_{2}$ é, então, separado por cromatografia de gás em condições isotérmicas e os gases são ionizados e acelerados no espectrômetro de massa. As diferentes massas são separadas em um campo magnético e simultaneamente medidas por multicolectores Faraday. Erros analíticos associados são estimados em $0,2 \%$. Os resultados analíticos são apresentados em per mil (\%०) na notação delta $\left(\delta^{18} \mathrm{O}, \delta^{13} \mathrm{C}\right.$ e $\left.\delta^{34} \mathrm{~S}\right)$ relativa aos padrões Valor - Standard Mean Ocean Water (V-SMOW)

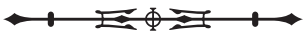


(oxigênio), Valor - Pee Dee Belemite (V-PDB) (carbono)e Valor - Canyon Diablo Troilite (V-CDT) (enxofre).

\section{ALVOS JERIMUM DE CIMA E BABI}

\section{ROCHAS HOSPEDEIRAS}

A amostragem de rochas para esse trabalho, nos alvos Jerimum de Cima e Babi, foi efetuada em testemunhos de sondagem de zonas mineralizadas e/ou alteradas hidrotermalmente, de forma que não foram obtidas amostras totalmente desprovidas de alteração hidrotermal. Em adição, não foram encontrados, em superfície, afloramentos de qualidade, sem alteração intempérica. Mesmo assim, com base na investigação das amostras menos alteradas, ou pouco alteradas, foi possível obter informações a respeito das rochas hospedeiras.

\section{Jerimum de Cima}

Azona mineralizada do alvo Jerimum de Cima está hospedada em granitoides classificados como biotita-hornblenda tonalito, monzogranito e granodiorito. Não há informação de como se dá a transição espacial entre esses tipos, que, provavelmente, representam variações faciológicas em um mesmo corpo. Texturas dessas rochas evidenciam relação com eventos que provocaram deformações, principalmente rúptil e localmente rúptil-dúctil.

O biotita-hornblenda tonalito é rocha porfirítica, de coloração rosada, com tons pretos e verdes, holocristalina, leucocrática e de granulação grossa. Os cristais são inequigranulares com o feldspato alcalino apresentando as maiores dimensões, variando de 15 a 22 mm (Figura 4A) e, por vezes, esverdeado, indicando alteração. Apresenta textura principal inequigranular porfirítica (Figura 4B). Os minerais essenciais estão representados por plagioclásio, quartzo e feldspato alcalino. Os minerais varietais estão representados por biotita e hornblenda. Apatita, minerais opacos e zircão representam as fases acessórias.

O monzogranito é porfirítico, de coloração cinza com tons rosados, holocristalino, leucocrático e de granulação grossa (Figura 4C). Microscopicamente, a rocha apresenta como textura principal granular hipidiomórfica, com plagioclásio, quartzo e feldspato alcalino representando os minerais essenciais (Figura 4D).

O granodiorito é fanerítico, de coloração cinza esbranquiçada, holocristalino, hololeucocrático e de granulação média a grossa (Figura 4E). Microscopicamente, apresenta textura principal granular halotriomórfica (Figura 4F). Os minerais essenciais são plagioclásio, quartzo e feldspato alcalino.

Babi

O alvo Babi está hospedado em granitoides classificados como titanita monzogranito, biotita monzogranito, biotitahornblenda tonalito e monzogranito.

titanita monzogranito é rocha porfirítica, com coloração cinza e tons esverdeados e rosados, holocristalina, mesocrática e de granulação média (Figura 5A). É composta por fenocristais de quartzo anédricos, com dimensões entre 2 e 25 mm; plagioclásio esverdeado anédrico e feldspato alcalino rosado anédrico a subédrico, com dimensões entre 2 e $10 \mathrm{~mm}$. Microscopicamente, a rocha apresenta textura principal porfirítica, ocorrendo localmente textura de intercrescimento mirmequítico (Figura 5E). Plagioclásio, quartzo e feldspato alcalino estão representando os minerais essenciais da rocha. Titanita e minerais opacos constituem os minerais acessórios.

O biotita monzogranito é rocha fanerítica de coloração cinza-esbranquiçada, holocristalina, hololeucocrática e de granulação média a grossa (Figura 5B). É composta por feldspato alcalino rosa-esbranquiçado anédrico, com dimensões entre 5 e 15 mm; plagioclásio esverdeado anédrico, com dimensões entre 4 e $12 \mathrm{~mm}$; e quartzo anédrico, com dimensões entre 3 e 15 mm. Microscopicamente, a rocha apresenta textura granular hipidiomórfica e localmente ocorrem texturas de intercrescimento mirmequítico e pertítico (Figura 5F). Os minerais essenciais são plagioclásio, feldspato alcalino e quartzo; biotita é o mineral varietal. 

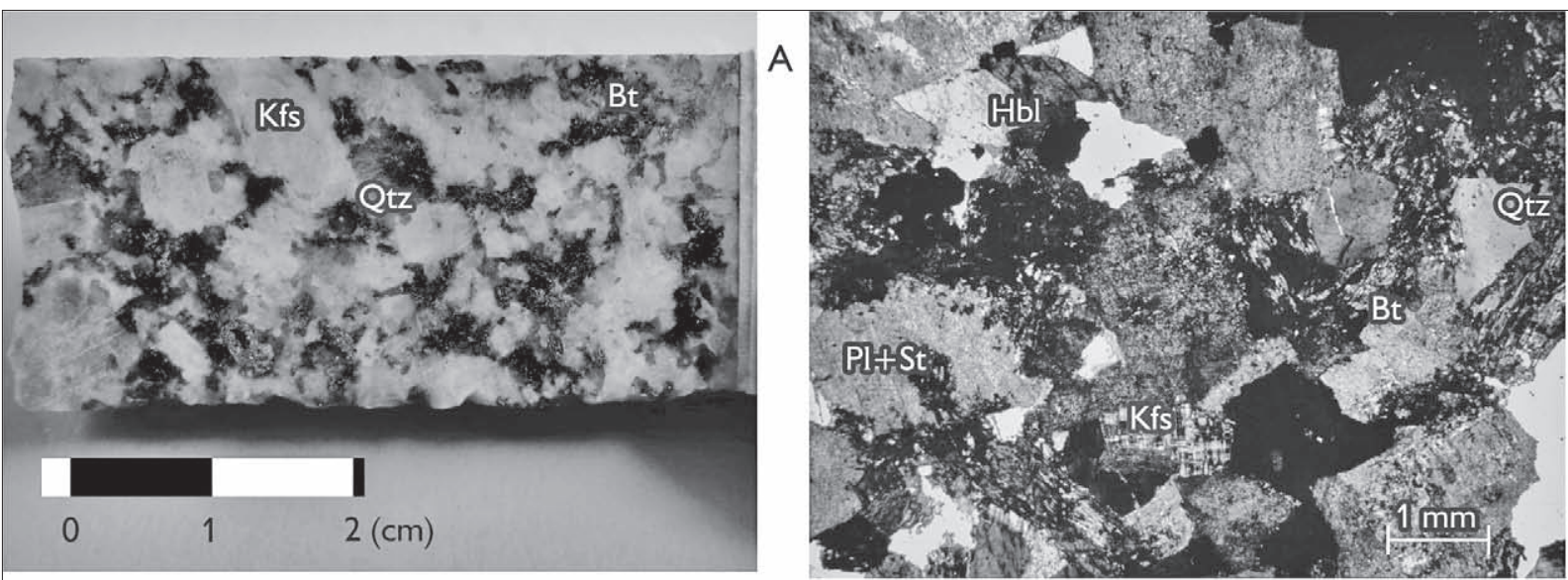

\section{$B$}
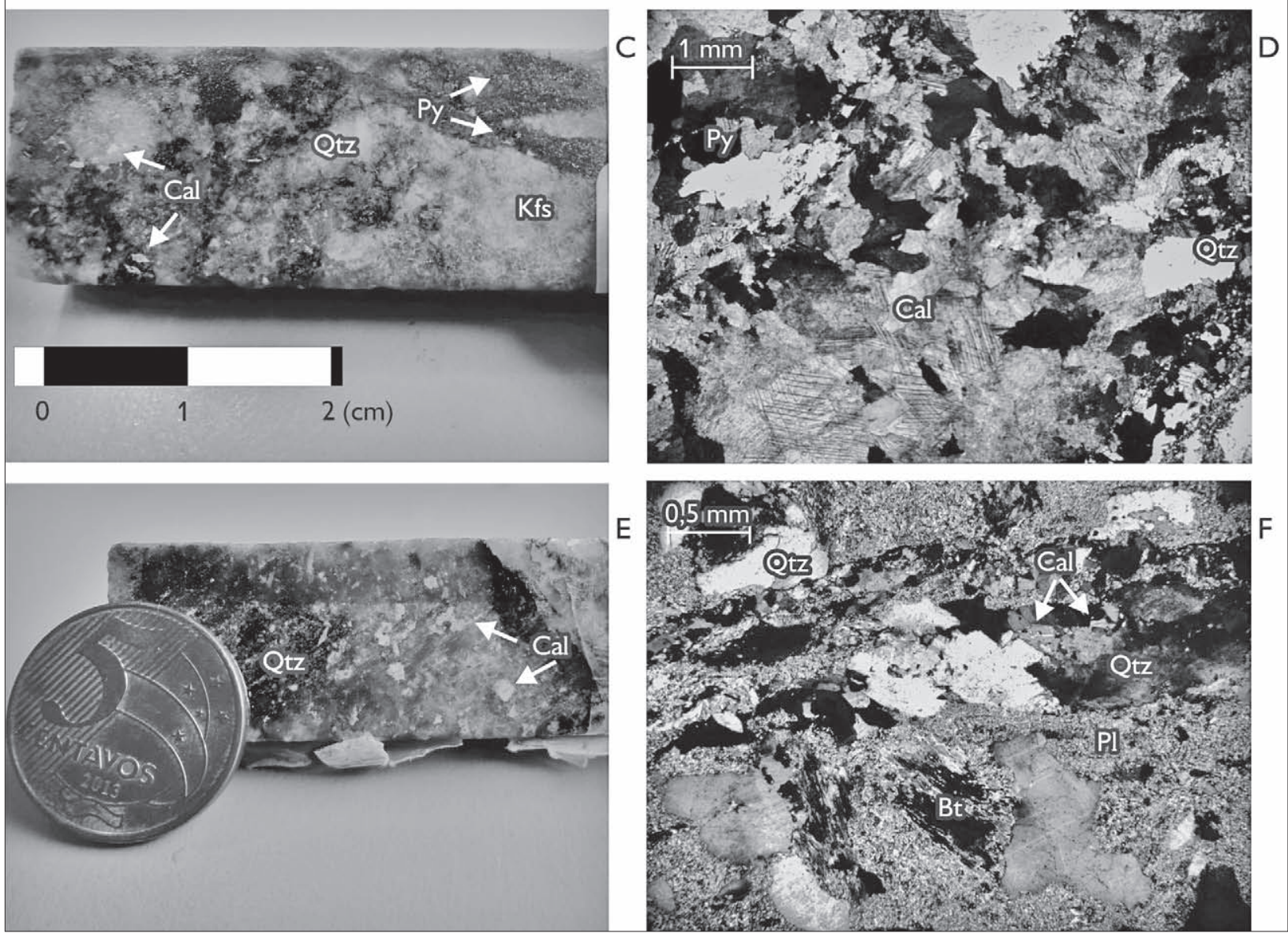

Figura 4. Aspectos macroscópicos e microscópicos das rochas hospedeiras do alvo Jerimum de Cima. A) Biotita-hornblenda tonalito porfirítico; B) fotomicrografia mostrando a textura inequigranular porfirítica do biotita-hornblenda tonalito. O plagioclásio indica forte alteração por sericitização. A biotita apresenta moderada alteração nas bordas. Indício de equilíbrio mineral entre quartzo e sericita; C) monzogranito apresenta textura porfirítica, cortada por redes de fraturas. Veio contendo pirita e esfalerita, indicando, assim, equilibrio na formação; D) textura principal granular hipidiomórfica do monzogranito, fortemente alterada por hidrotermalismo; E) granodiorito apresenta textura fanerítica, fortemente fraturada, preenchida por pirita, quartzo e calcita, indicando equilíbrio mineral; F) textura granular halotriomórfica, com forte alteração de minerais máficos. Abreviações: $\mathrm{Pl}=$ plagioclásio, $\mathrm{Qtz}=$ quartzo, $\mathrm{St}=$ sericita, $\mathrm{Kfs}=$ feldspato alcalino, $\mathrm{Bt}=$ biotita, $\mathrm{Hbl}=$ hornblenda, $\mathrm{Py}=$ pirita, $\mathrm{Cal}=$ calcita .

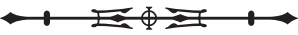



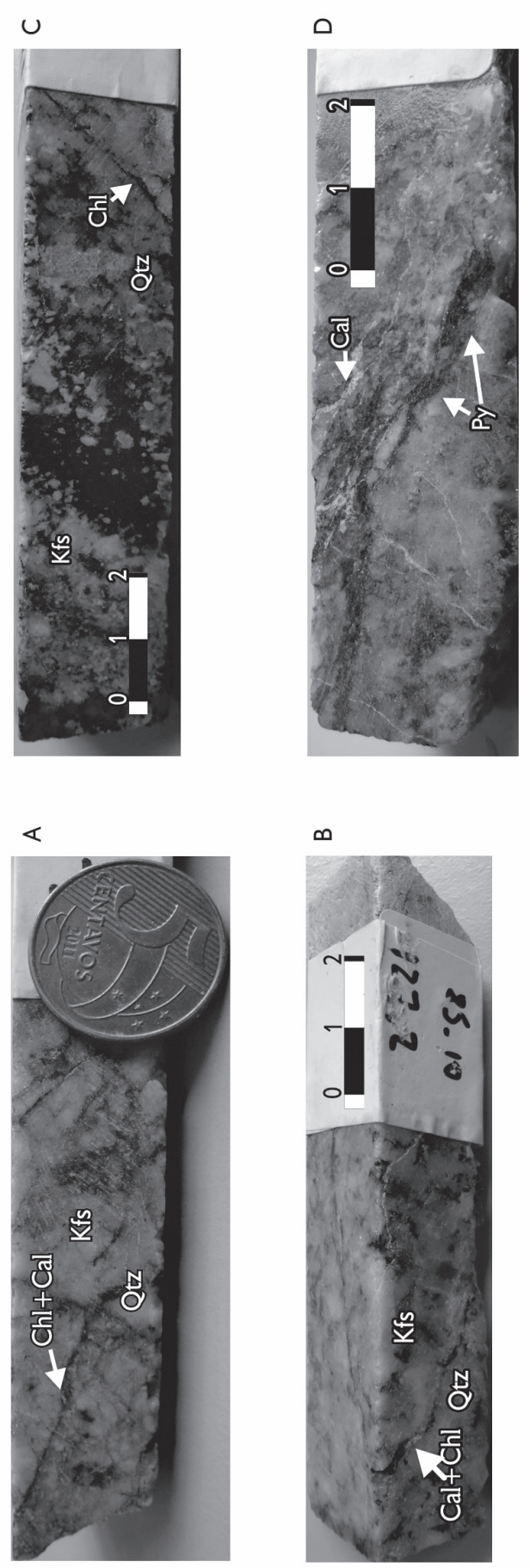

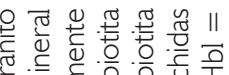

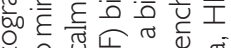

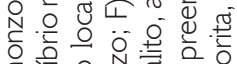

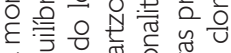

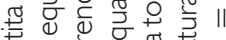

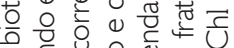

周 듕

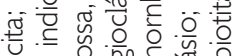

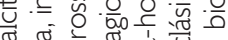

उ.

ब

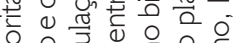

월

항

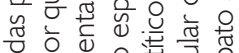

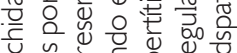

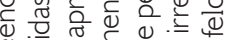

¿ํ.

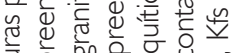

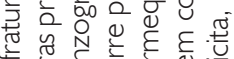

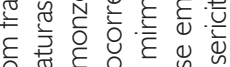

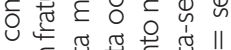

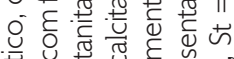

है

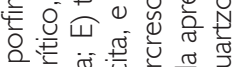

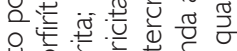

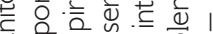

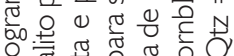

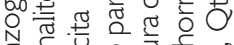

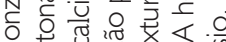

ह

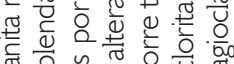

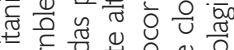

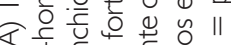

-

贾. 흠

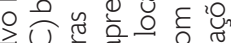

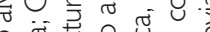

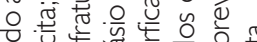

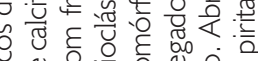

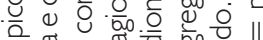

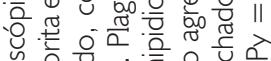

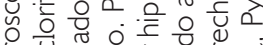

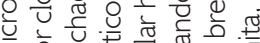

ह

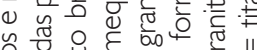

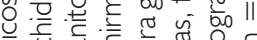

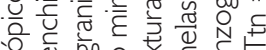

ब

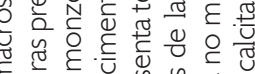

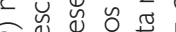

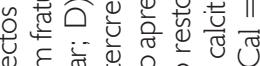

ब

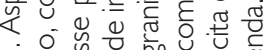

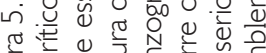

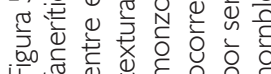


O biotita-hornblenda tonalito é porfirítico com matriz inequigranular, de coloração rosada com tons pretos, holocristalino, leucocrático e com granulação variando de média a grossa (Figura 5C). É composto por feldspato alcalino rosado anédrico a subédrico, quartzo anédrico e plagioclásio verde-esbranquiçado anédrico. Os cristais são inequigranulares, e o feldspato alcalino apresenta as maiores dimensões. Microscopicamente, a textura principal é granular hipidiomórfica (Figura 5G). Plagioclásio, quartzo e feldspato alcalino são os minerais essenciais da rocha. Os minerais varietais são biotita e hornblenda.

O monzogranito brechado é fanerítico, de cor cinzaesverdeada com tons pretos, holocristalino, leucocrático e de granulação média (Figura 5D). Microscopicamente, a rocha apresenta textura principal granular alotriomórfica e, localmente, textura de intercrescimento mirmequítico e pertítico. Plagioclásio, quartzo e feldspato alcalino são os minerais essenciais da rocha. O plagioclásio apresenta formas anédricas a subédricas, comalguns cristais alterando para sericita, com fraturas preenchidas por sericita e calcita (Figura $5 \mathrm{H}$ ).

\section{ALTERAÇÃO HIDROTERMAL E MINERALIZAÇÃO}

Nos alvos Jerimum de Cima e Babi, minerais magmáticos (quartzo, plagioclásio, feldspato alcalino, biotita, hornblenda e titanita) em rochas menos alteradas apresentam-se bem preservados (Figura 6). Os dois alvos apresentam diferente comportamento em relação à alteração hidrotermal, principalmente na intensidade de ocorrência (Figura 7). Dois estilos de alteração hidrotermal são observados: pervasivo (predominantemente seletivo) e fissural (Figuras 6 e 8). Com o avanço da alteração pervasiva, caracterizado como o primeiro estágio de formação (Estágio I), sericita é originada do plagioclásio, sendo que clorita substitui a biotita e a hornblenda. A alteração fissural, descrita como o segundo estágio de ocorrência (Estágio II), é definida pela precipitação de quartzo, calcita, pirita e clorita em fraturas das rochas hospedeiras. Sericitização, silicificação e sulfetação ocorrem mais intensamente no alvo Jerimum de Cima, enquanto cloritização e carbonatação ocorrem de modo equivalente nos dois alvos (Figuras 6 e 7).

Com relação à mineralização, apesar de amostras de zonas mineralizadas do alvo Jerimum de Cima terem sido investigadas neste trabalho e de relatório da mineradora Magellan Minerals Ltd. (2011) mostrar teores de ouro entre 1,1 e 13,3 ppm (e valores isolados de até 345,8 ppm), não foi possível identificar partículas de ouro nesse alvo nem na investigação petrográfica convencional, nem com uso de MEV. O relatório da Magellan Minerals Ltd. (2011)

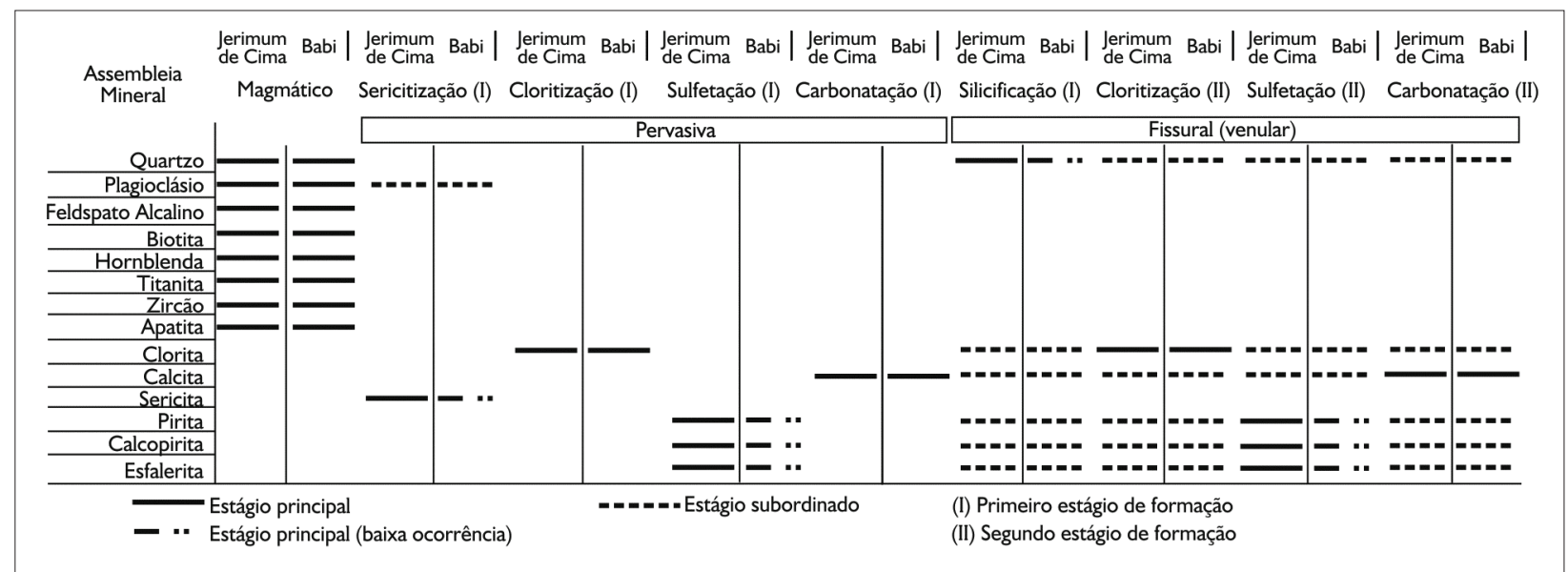

Figura 6. Estilos de alteração hidrotermal nos depósitos Jerimum de Cima e Babi, e suas principais associações minerais observadas nos diferentes estágios de evolução das rochas dos dois alvos.

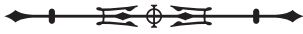




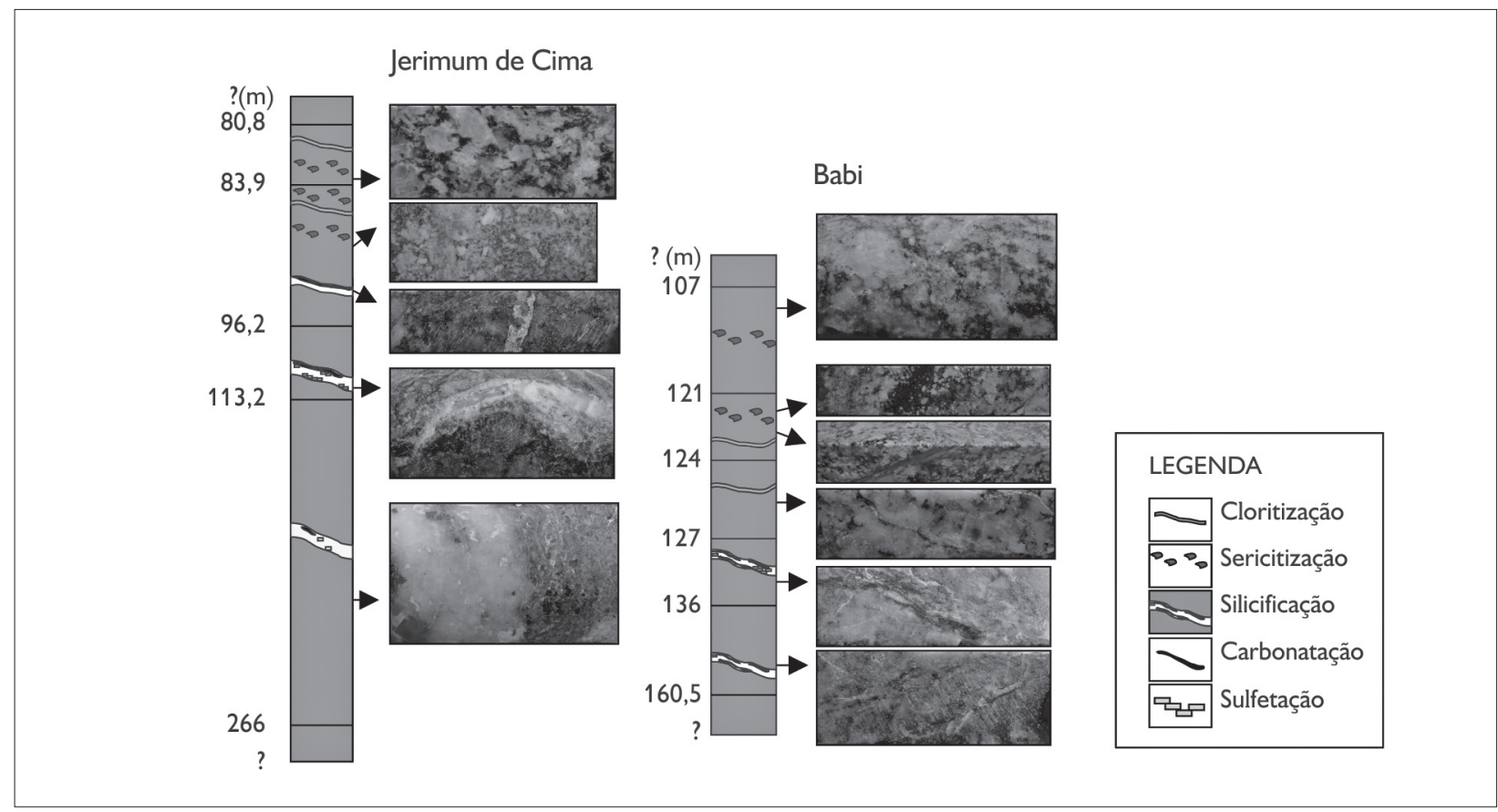

Figura 7. Perfil esquemático representando a posição de ocorrência dos tipos de alteração hidrotermal nos alvos Jerimum de Cima e Babi.

ressalta, contudo, que a mineralização, em geral, correlaciona positivamente com o conteúdo de sulfetos e que o ouro ocorre em fraturas de pirita, entre cristais de pirita e raramente como inclusão nesse mineral. Isso mostra ser a sulfetação a alteração claramente relacionada com a mineralização.

No alvo Babi também não foram identificadas partículas de ouro. Magellan Minerals Ltd. (2011) reportou teores de ouro entre 1,3 e 1,6 ppm, mas em apenas três intersecções, ressaltando o caráter "não mineralizado" desse alvo.

\section{Sericitização}

Esta é a alteração pervasiva de caráter seletivo mais expressiva no alvo Jerimum de Cima, mas ocorre também no alvo Babi. A sericita substitui cristais de plagioclásio (Figuras 8A e 8B) e, por vezes, é produto da desferrificação da biotita. Está também presente em fraturas que ocorrem no plagioclásio e no quartzo. Em ambos os casos, os cristais são muito finos.

\section{Cloritização}

Esta alteração ocorre intensamente nos dois alvos de forma pervasiva seletiva (Estágio I) (Figura 8A). A presença de clorita ferrosa, de coloração esverdeada e hábito vermicular, é uma característica forte nesta alteração, sendo resultado da substituição parcial ou total da biotita e hornblenda magmática. A clorita ocorre com formas anédricas, e em contato com biotita, sericita, calcita e plagioclásio. Por vezes, a clorita ocorre também - classificado neste trabalho como o segundo estágio de ocorrência (Estágio II) - em veios de assembleia quartzo + calcita + clorita + pirita (Figura 8B).

\section{Silicificação}

Esta alteração é mais comum no alvo Jerimum de Cima, no entanto, foi identificada também no alvo Babi. Ocorre em veios monominerálicos do tipo maciço, por vezes do tipo crusti, que são marcantes no alvo Jerimum de Cima, em veios de quartzo-calcita (Figuras $8 \mathrm{G} \mathrm{e} 8 \mathrm{H}$ ), ou em veios poliminerálicos, de associação quartzo + calcita \pm clorita + pirita (Figuras 8D e 8F).

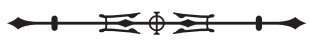



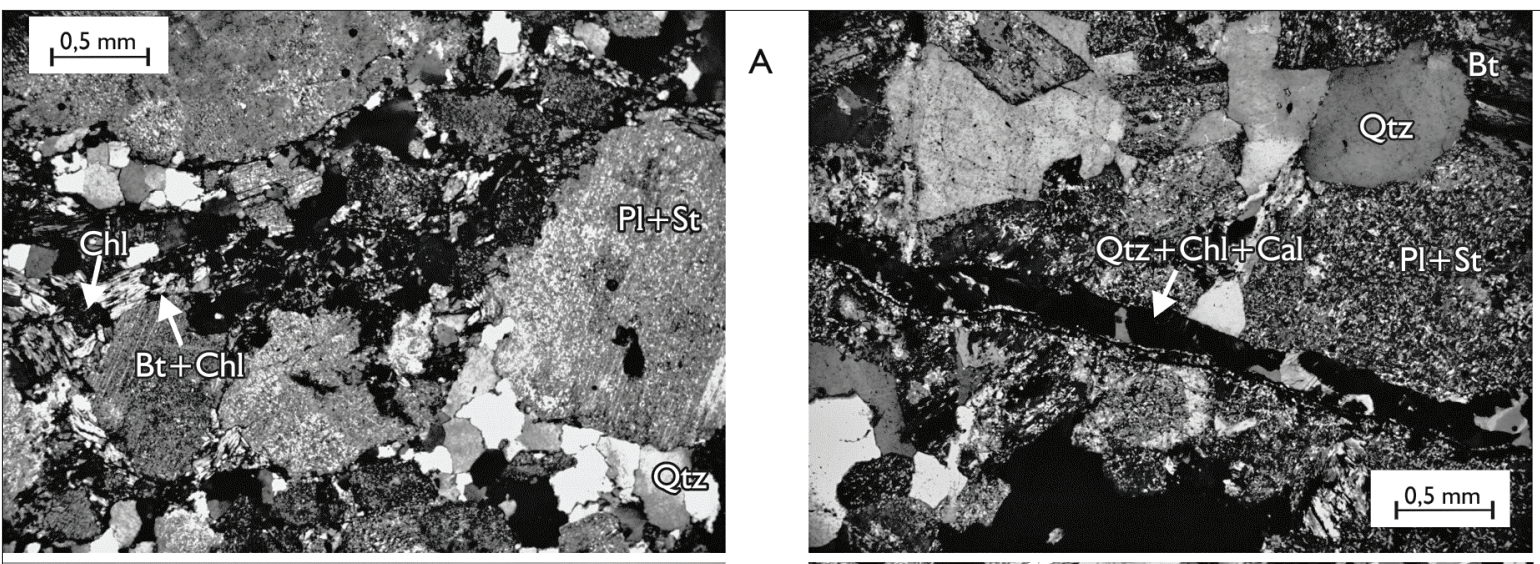

\section{B}

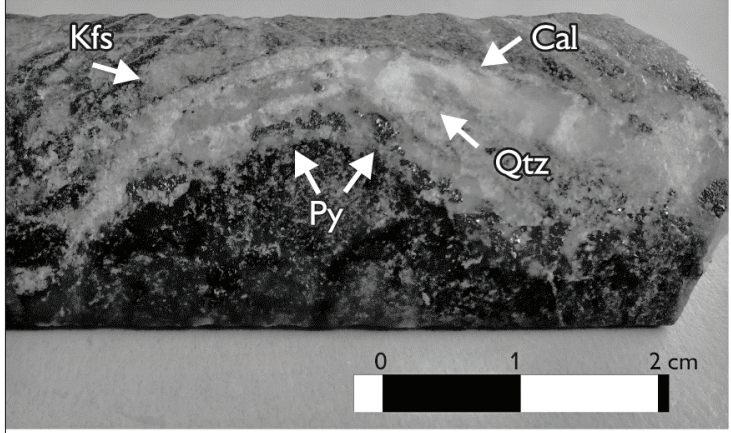

C
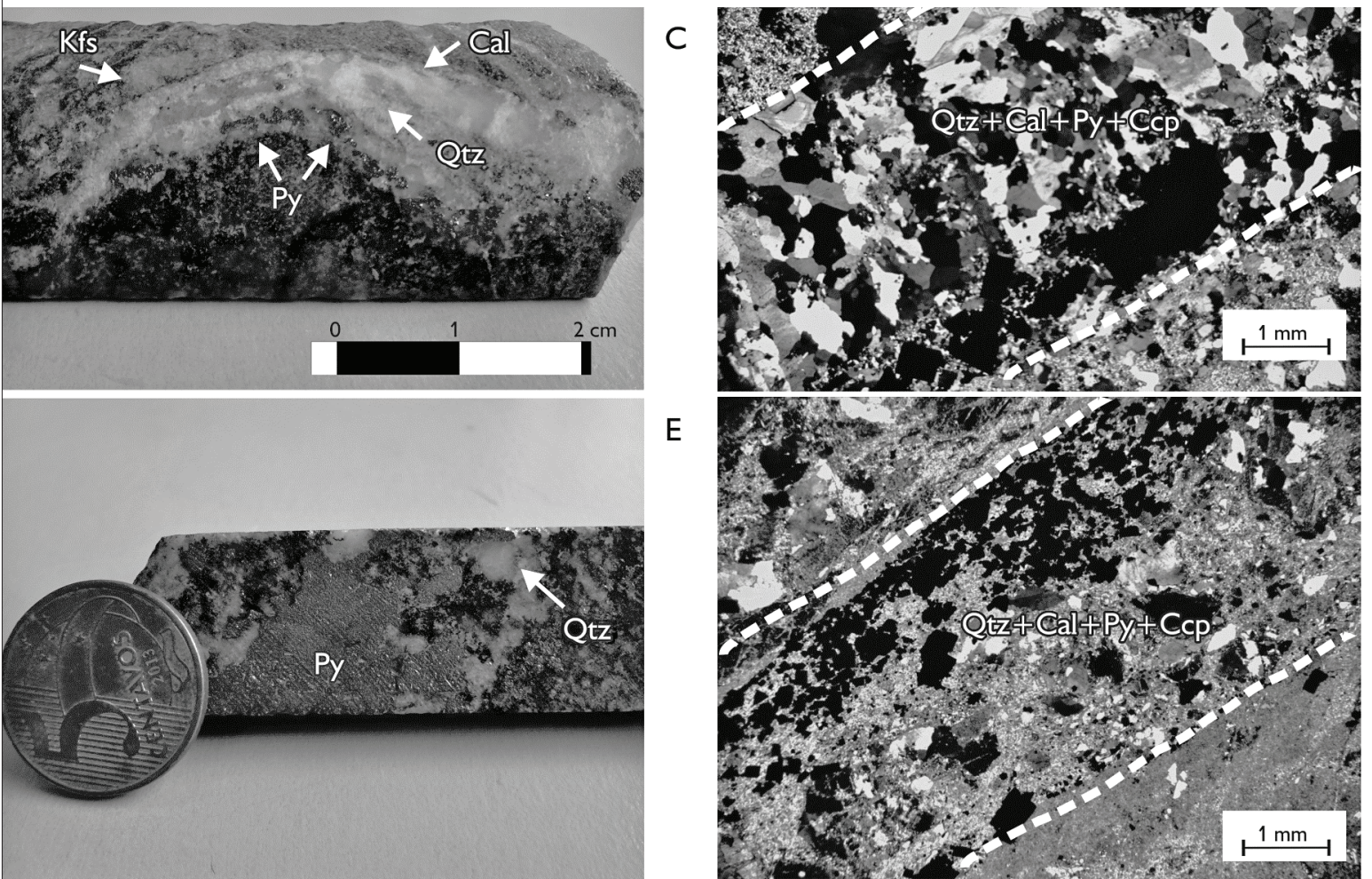

E
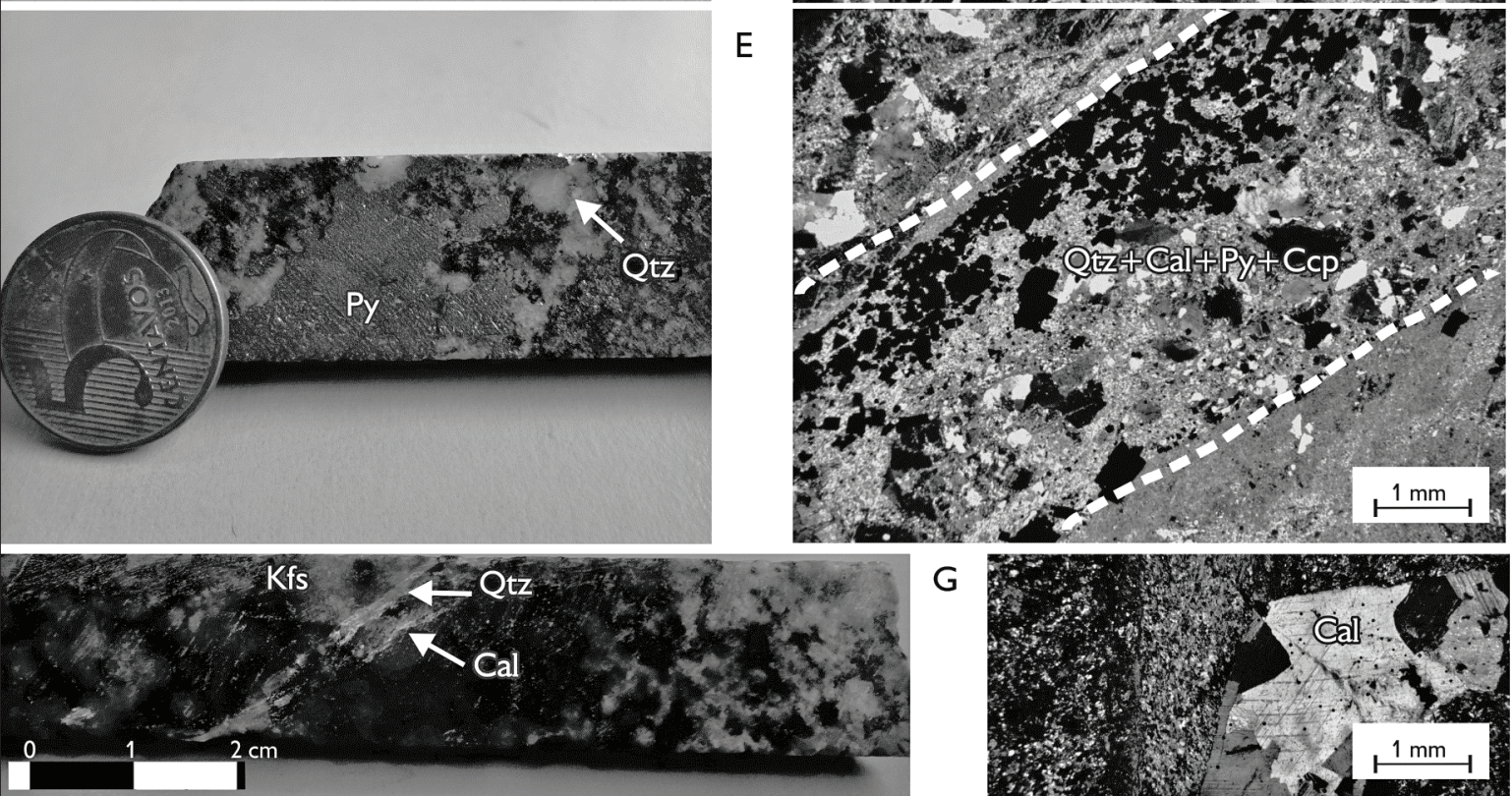

G

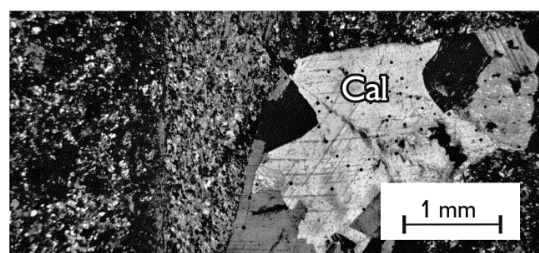

Figura 8. A) Sericitização e cloritização de origem pervasiva seletiva em tonalito do alvo Babi. $\bigcirc$ plagioclásio apresenta forte alteração para sericita e a biotita indica alteração para a clorita; B) cloritização de caráter fissural em granodiorito do alvo Jerimum de Cima; Ce D) silicificação, sulfetação e carbonatação fissural em monzogranito do alvo Jerimum de Cima; E) sulfetação de caráter pervasivo em tonalito do alvo Jerimum de Cima; F) silicificação, sulfetação e carbonatação fissural em monzogranito do alvo Babi; G) microvênulas preenchidas por calcita e quartzo em tonalito do alvo Jerimum de Cima; H) carbonatação de estilo pervasivo em monzogranito do alvo Babi. Abreviações: Pl = plagioclásio, Qtz = quartzo, St = sericita, Kfs = feldspato alcalino, Bt = biotita, Chl = clorita, Cal = calcita, Py = pirita, Ccp = calcopirita. 


\section{Sulfetação}

Esta alteração é marcada, em Jerimum de Cima, pela precipitação de pirita, mais abundante, esfalerita, calcopirita, galena e ouro. Neste trabalho, foram classificados dois estágios desta alteração: o primeiro estágio tem o estilo pervasivo (Figura 8E) e o segundo estágio apresenta $\mathrm{O}$ estilo fissural (Figuras 8C, 8D e 8F), em veio de quartzo + calcita + sulfeto. No alvo Babi, esta alteração ocorre fracamente. $\bigcirc$ estilo disseminado da alteração é a forma mais encontrada neste alvo.

\section{Carbonatação}

A carbonatação apresentou-se de forma equivalente nos dois alvos. Esta alteração representa a precipitação de calcita, que ocorre com formas subédricas a anédricas.

Esta alteração apresenta dois estágios: o primeiro tem o estilo pervasivo (Figura 8H), caracterizado pela alteração do plagioclásio; o segundo apresenta o estilo de caráter fissural, em veio de quartzo-calcita (Figura $8 \mathrm{G}$ ) ou de associação quartzo + calcita \pm clorita + pirita + calcopirita (Figuras 8B, 8C e 8D).

No alvo Jerimum de Cima, os sulfetos ocorrem de forma disseminada (Figuras 9A e 9B), em microfraturas e, dominantemente, em veios de quartzo e/ou sulfetos de espessuras milimétricas a centimétricas (Figuras $9 \mathrm{C}$ e 9D). Ao microscópio, a pirita ocorre como cristais subédricos, por vezes, com forma euédrica. Apresenta dimensões que variam de 0,5 a 3,5 mm (Figuras 10A e 10D);
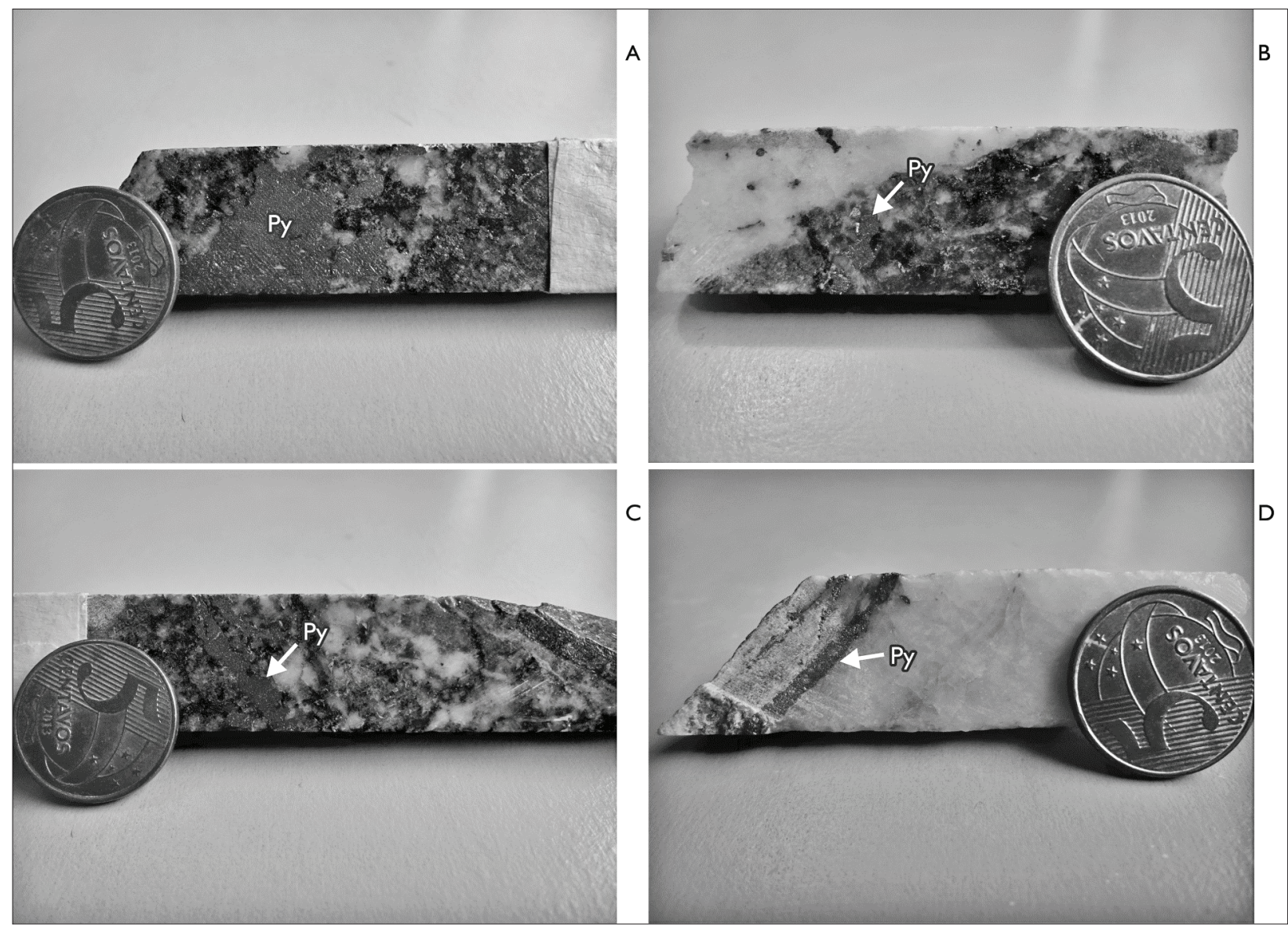

Figura 9. Testemunhos de sondagem do alvo Jerimum de Cima, mostrando sulfetação. A e B) Pirita disseminada em monzogranito; C) fratura preenchida por pirita; D) vênula de pirita na borda de um veio de quartzo. Abreviação: Py = pirita.

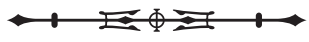


por vezes, em contato com titanita (Figura 10B) e calcita (Figuras 10E e 10F); esfalerita (Figura 10C), esta por vezes está inclusa na pirita (Figura 10E); calcopirita (Figura 10E) e com inclusões de galena (Figura 10F). Por vezes, a pirita apresenta-se corroída ou fortemente fraturada. A esfalerita forma pequenos cristais anédricos, que fazem contato irregular com a pirita e, por vezes, está inclusa na pirita (Figuras $10 \mathrm{C}$ e 10E). A calcopirita apresenta formas anédricas e grande parte está inclusa na pirita ou em contato com esta (Figura 10E). A galena ocorre raramente neste alvo, apenas foi observada com uso de MEV, inclusa na pirita (Figura 10F). As texturas dos sulfetos indicam ação estrutural de deformação após a sulfetação, principalmente rúptil-dúctil.

No alvo Babi, a sulfetação ocorre de uma maneira mais incipiente, e os sulfetos não se apresentam bem formados. A pirita é também o sulfeto mais abundante neste alvo. A sulfetação ocorre em pontos isolados (Figuras $11 \mathrm{~A}, 11 \mathrm{~B}$ e 11C), por vezes associada a veios de quartzo (Figura 11D). Ao microscópio, a pirita apresenta-se com formas subédricas a anédricas, com dimensões entre 0,2 e $5 \mathrm{~mm}$. Por vezes, ocorre isoladamente, em contato com titanita (Figura 12A) e calcopirita (Figura 12B), associada a veios de quartzo (Figura 12C) ou associada irregularmente com a esfalerita (Figura 12D). A esfalerita ocorre raramente, às vezes isolada ou associada à pirita (Figura 12D). A calcopirita apresenta baixa ocorrência no alvo, quase sempre inclusa na pirita (Figura 12B). Diferentemente do observado no alvo Jerimum de Cima, foi constatado um controle estrutural incipiente para a sulfetação.

\section{INCLUSÕES FLUIDAS}

\section{TIPOS E DISTRIBUIÇÃO}

O estudo de inclusões fluidas (IF) foi realizado em quartzo de veios e agregados hospedados em diversos granitoides dos dois alvos, fracamente a fortemente alterados (Figuras 13A, 13B, 14A e 14B). Observou-se que os cristais de quartzo localizados em veios dos alvos Jerimum de Cima e Babi, geralmente fortemente fraturados (Figura 13C), apresentam poucas inclusões e com tamanhos inferiores a $5 \mu \mathrm{m}$. Cristais de quartzo em agregados nas zonas de alteração (silicificação) apresentam inclusões maiores e mais bem definidas.

No alvo Jerimum de Cima, as IF ocorrem em grupos, isoladas ou em trilhas. Observações em temperatura ambiente e durante o resfriamento permitiram a definição de três tipos. O Tipo 1 é composto por inclusões carbônicas, com uma fase $\left(\mathrm{CO}_{\text {2vapor }}\right)$, ou duas fases $\left(\mathrm{CO}_{\text {2liquido }}-\mathrm{CO}_{\text {2vapor }}\right)$. Este tipo ocorre fracamente neste alvo, geralmente associado com as IF do Tipo 2, e está sempre com evidência de vazamento e/ou estrangulamento. Mostra formas bem distintas, na grande maioria irregular e com tamanho médio de $6 \mu \mathrm{m}$ (Figura 13D). O Tipo 2, inclusões aquocarbônicas, apresenta duas ou três fases, $\mathrm{H}_{2} \mathrm{O}_{\text {liquido }}-\mathrm{CO}_{\text {2liquido }}$ e $\mathrm{H}_{2} \mathrm{O}_{\text {liquido }}$ - $\mathrm{CO}_{\text {2liquido }}-\mathrm{CO}_{\text {2vapor }}$ respectivamente. Este tipo geralmente ocorre em grupos ou em trilhas. Apresenta bastante variação na morfologia das inclusões, por vezes cilíndrica, irregular, elipsoidal, arredondada, cristal negativo, com tamanho bem variado, de 5 a $16 \mu \mathrm{m}$ (Figuras 13D e 13F). Nessas inclusões, a fase carbônica $\left(\mathrm{CO}_{\text {2vapor }}+\mathrm{CO}_{\text {2liquido }}\right)$ representa $50 \mathrm{a}$ $90 \%$ do volume total das cavidades. O Tipo 2 encontra-se frequentemente associado com o Tipo 1 e, por vezes, com o Tipo 3. As IF compostas por duas fases $\left(\mathrm{H}_{2} \mathrm{O}_{\text {liquido }}-\mathrm{H}_{2} \mathrm{O}_{\text {vapor }}\right)$ são classificadas como Tipo 3 ou aquosas. Este tipo é o mais abundante deste alvo; as IF geralmente ocorrem em grupos, podendo ser observadas isoladas ou em trilhas, com grande variação na sua morfologia (cilíndrica, irregular, cristal negativo, elipsoidal, retangular) e grande variação no tamanho, de 5 a $13 \mu \mathrm{m}$. $\bigcirc$ grau de preenchimento varia de 0,2 a 0,9 (Figuras 13E e 13F). Este tipo ocorre associado com o Tipo 2.

O Tipo 3 é o único encontrado no alvo Babi. Geralmente é composto por duas fases $\left(\mathrm{H}_{2} \mathrm{O}_{\text {lliquido }}-\mathrm{H}_{2} \mathrm{O}_{\text {vapor }}\right)$, ou até mesmo por uma única fase, a qual se apresentou metaestável. Comumente as inclusões ocorrem isoladas (Figura 14F), por vezes em grupo (Figuras14C, 14D e 14E); com formas cilíndricas, retangulares, irregulares, arredondadas; com pequena variação no tamanho, de 4 a $9 \mu \mathrm{m}$; e com grau de preenchimento que varia de 0,1 a 0,6. 

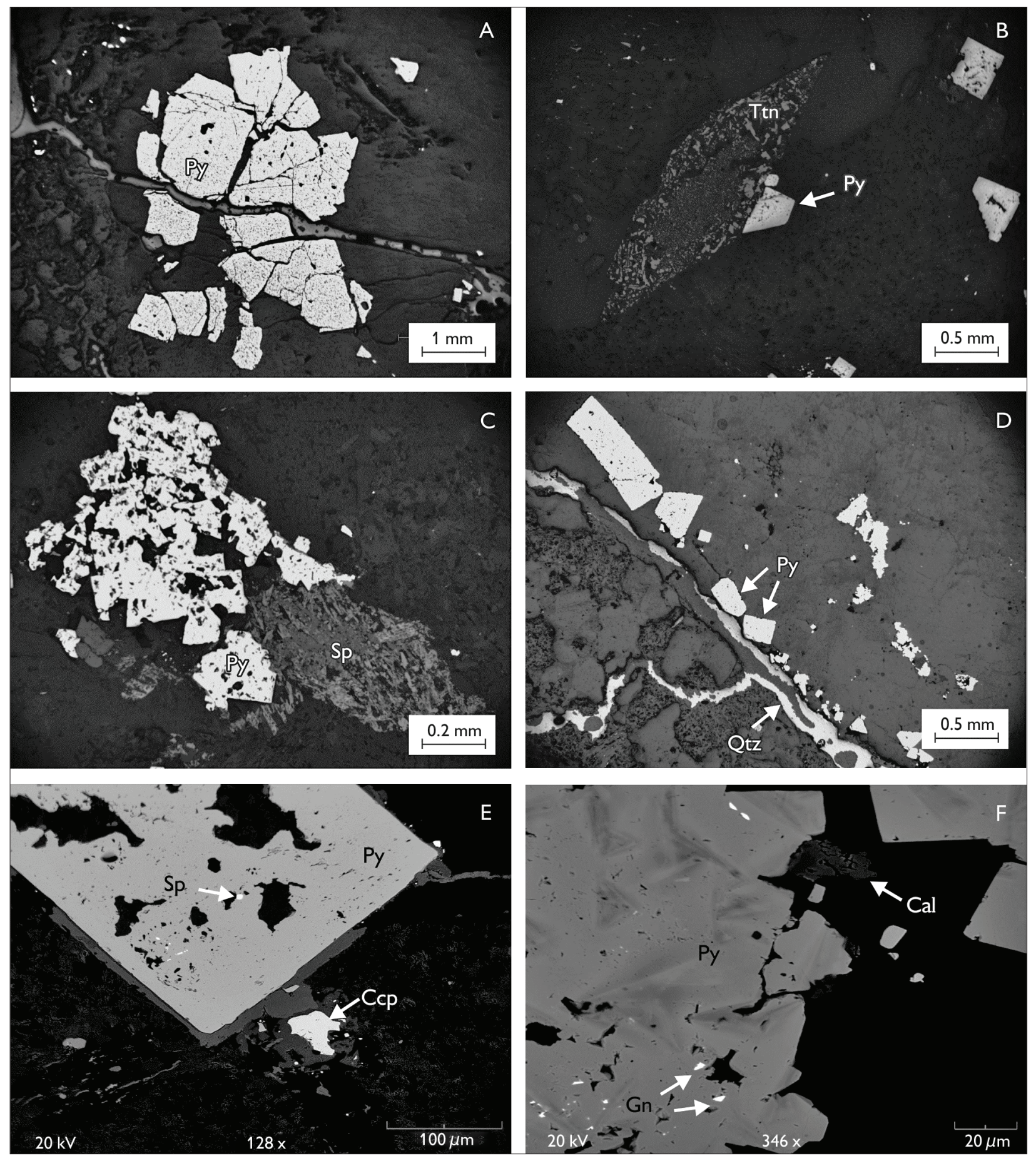

Figura 10. Fotomicrografias de porções sulfetadas no alvo Jerimum de Cima. A) Pirita fortemente fraturada e cortada por microvênulas de quartzo; B) pirita em contato brusco com restos de titanita; C) pirita anédrica com aspecto corroído em contato com esfalerita; D) pirita disseminada nas proximidades de microvênula de quartzo; E) imagem por MEV, mostrando inclusão de esfalerita em pirita subédrica e calcopirita englobada por calcita; F) imagem por MEV mostrando inclusões de galena em cristal de pirita em contato com calcita. Abreviações: Py = pirita, $\mathrm{C} c p=$ calcopirita, $\mathrm{Sp}=$ esfalerita, $\mathrm{Gn}=$ galena, $\mathrm{Cal}=$ calcita, Ttn $=$ titanita, Qtz = quartzo. 

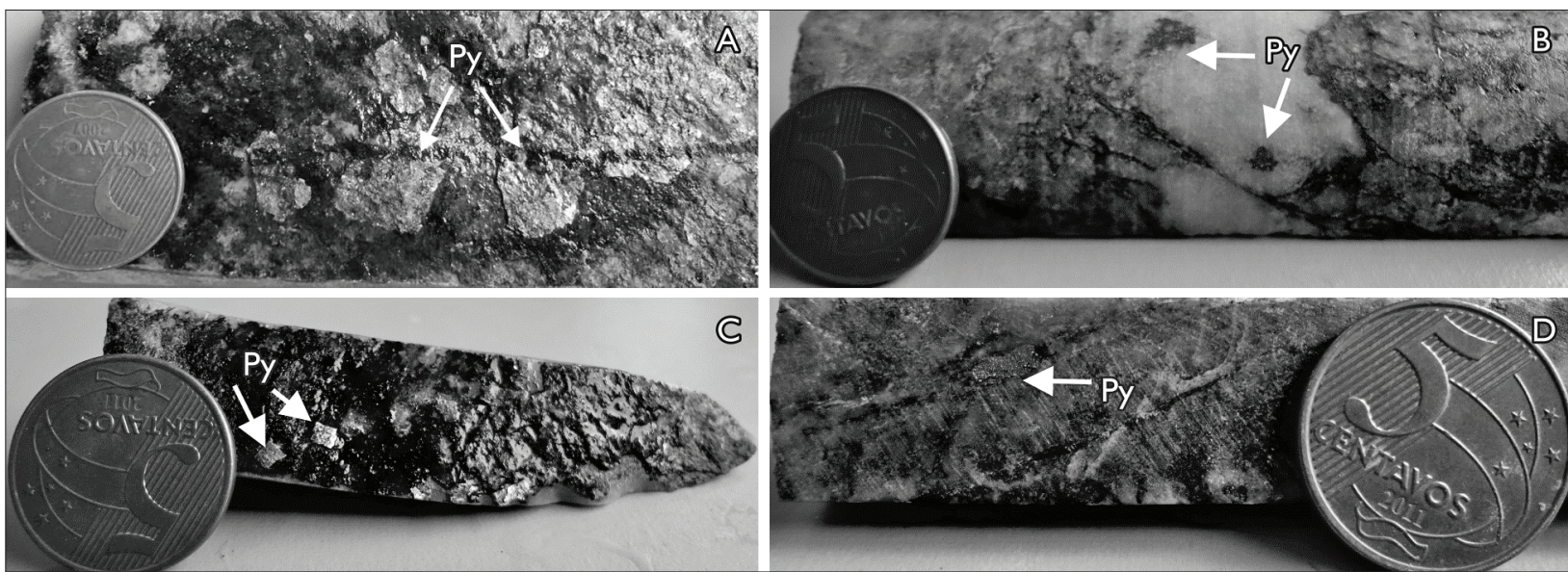

Figura 11. Sulfetação no alvo Babi. A e C) Pirita subédrica em monzogranito; B) pirita em veio de quartzo; D) pirita anédrica na borda de veio de quartzo. Abreviação: Py $=$ pirita.

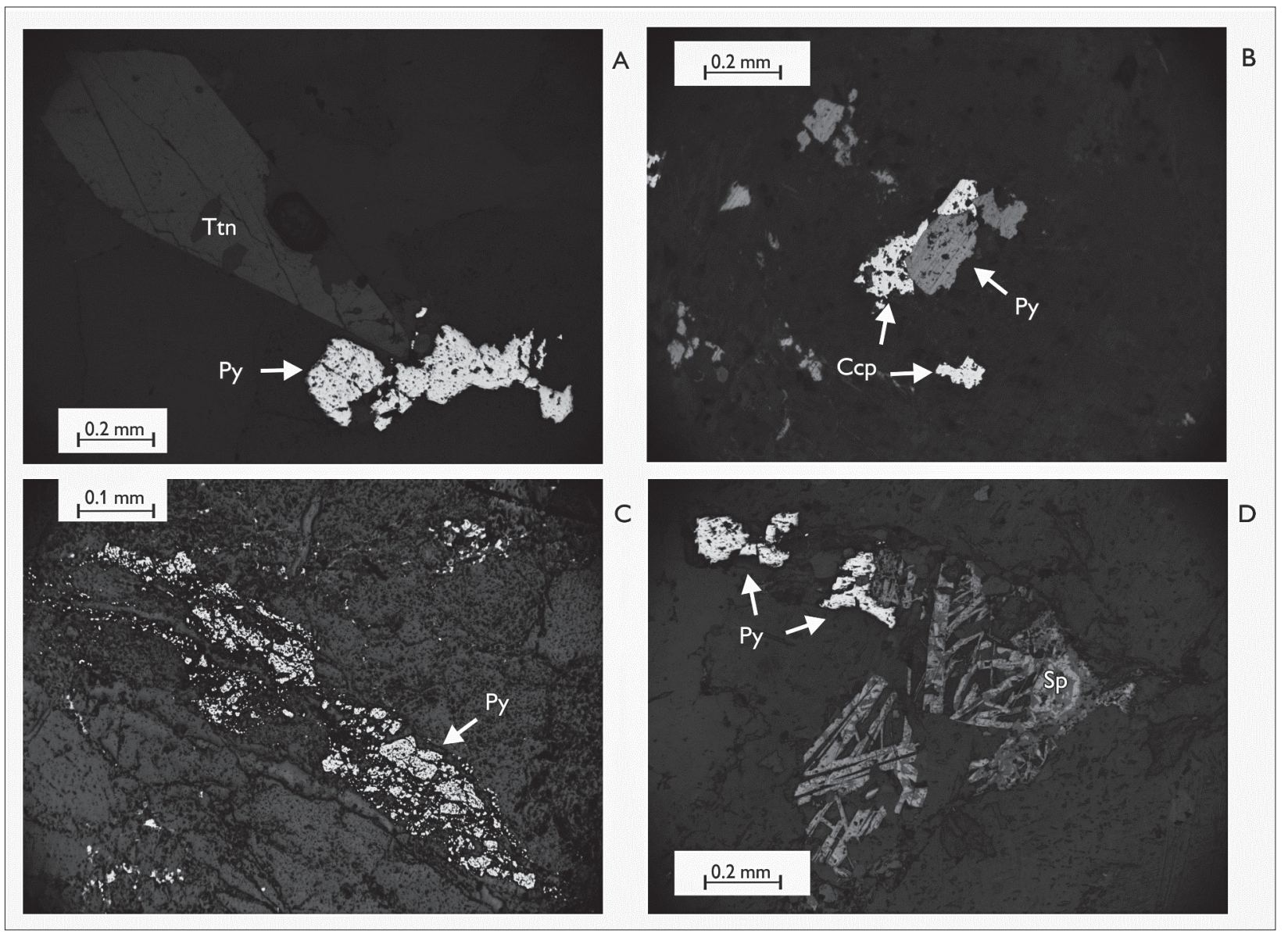

Figura 12. Fotomicrografias de sulfetos do alvo Babi. A) Pirita anédrica associada com titanita; B) pirita em contato com calcopirita; C) pirita fortemente oxidada, associada com veio de quartzo; D) pirita associada com esfalerita. Abreviações: Py $=$ pirita, $\mathrm{Ccp}=\mathrm{calcopirita,} \mathrm{Sp}=$ esfalerita, Ttn $=$ titanita

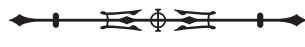



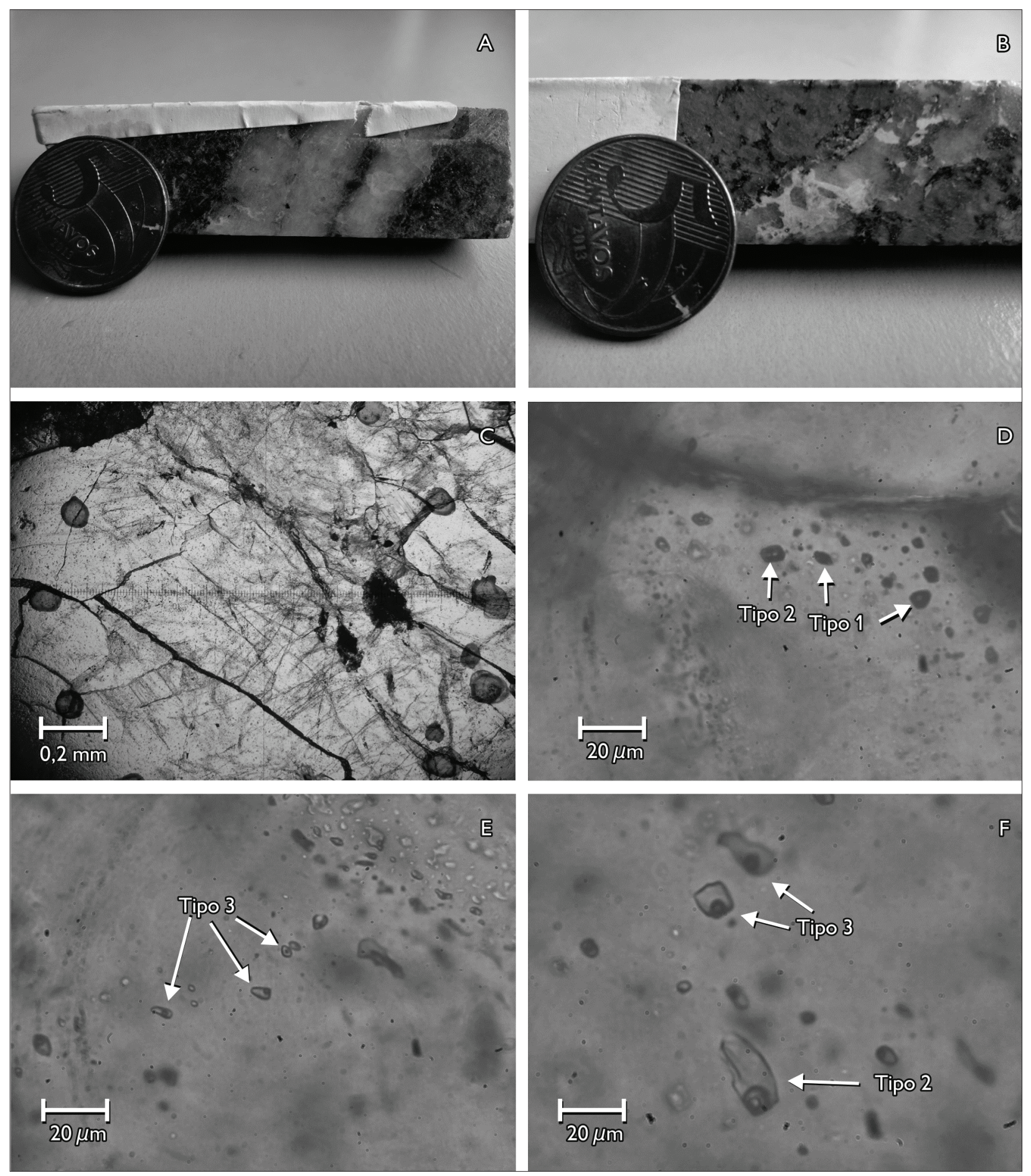

Figura 13. A e B) Aspectos macroscópicos dos veios hospedeiros e das inclusões fluidas do alvo Jerimum de Cima. Aspectos das inclusões em fotomicrografias; C) pontos escuros indicam a localização das inclusões fluidas no quartzo de veio fraturado; D) ocorrência de inclusões dos Tipos 1 e 2 próximas do limite do cristal do quartzo; E) inclusões do Tipo 3 que ocorrem em agrupamento de poucas inclusões, próximo à trilha de inclusões do mesmo tipo; F) inclusões dos Tipos 2 e 3 em proximidade espacial.

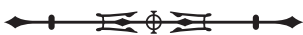




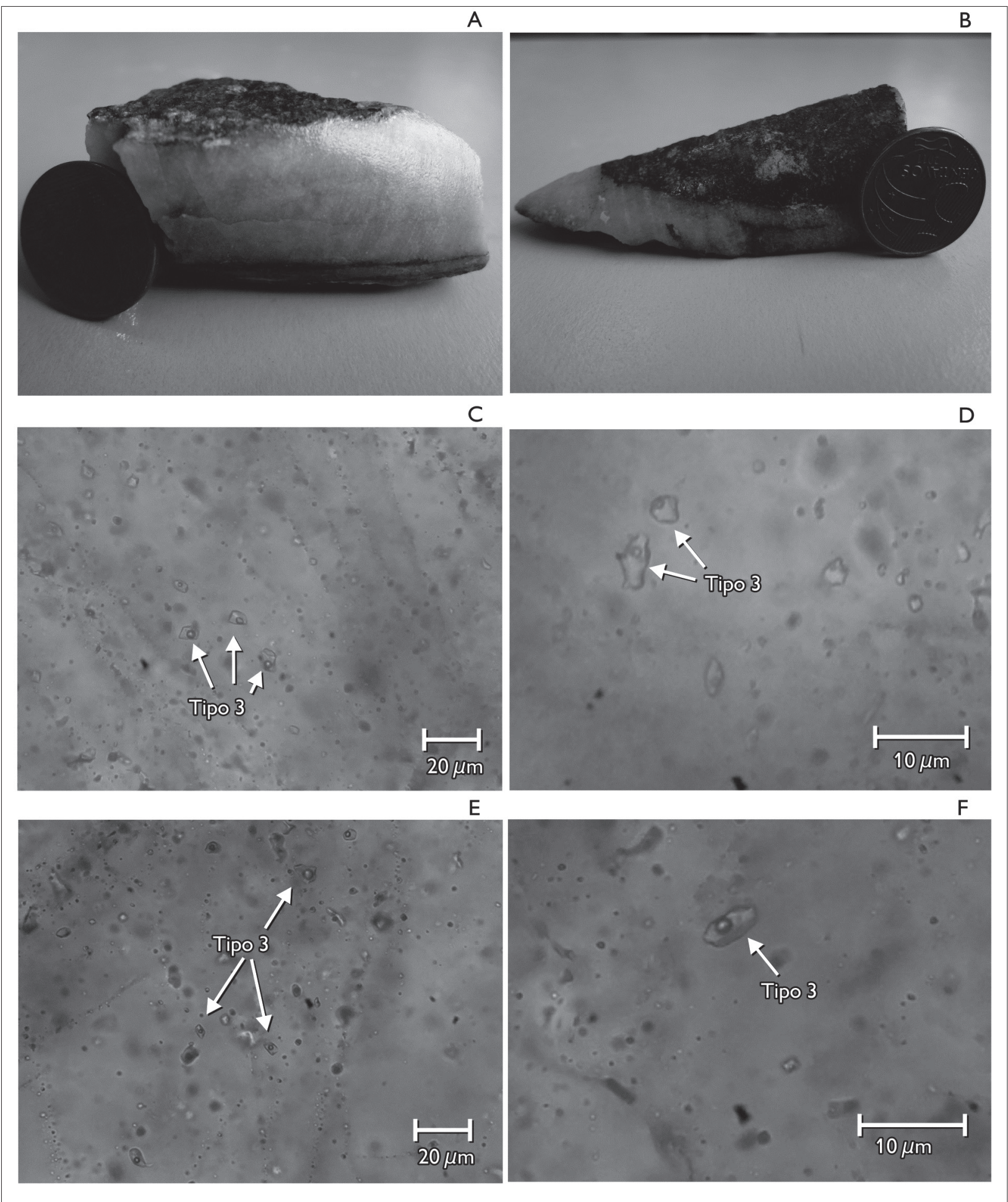

Figura 14. A e B) Veios de quartzo do alvo Babi a partir dos quais foram feitas as lâminas bipolidas, para estudo das inclusões fluidas; C, D e E) inclusões do Tipo 3 em agrupamentos; F) ocorrência de inclusão do Tipo 3 isolada no veio.

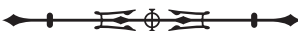




\section{RESULTADOS MICROTERMOMÉTRICOS}

As temperaturas de mudanças de fase obtidas no estudo microtermométrico serão referidas a seguir, no texto e nas figuras, com as seguintes abreviaturas: $\mathrm{TfCO}_{2}=$ temperatura de fusão do $\mathrm{CO}_{2} ; \mathrm{ThCO}_{2}=$ temperatura de homogeneização do $\mathrm{CO}_{2} ;$ TfClat = temperatura de fusão do clatrato; Tht = temperatura de homogeneização total; $\mathrm{Tfg}=$ temperatura de fusão do gelo.

\section{Alvo Jerimum de Cima}

Não foram obtidos dados microtermométricos para as inclusões carbônicas (Tipo 1), pois se apresentam com vazamento (parcial ou total) ou estranguladas. As inclusões aquocarbônicas (Tipo 2) apresentaram $\mathrm{TfCO}_{2}$ entre $-56,7$ e $-58,7^{\circ} \mathrm{C}$ (Figura 15A). A $\mathrm{ThCO}_{2}$ nessas mesmas inclusões mostrou valores entre 27,4 e $31,4^{\circ} \mathrm{C}$ (Figura 15B), sempre ocorrendo para o estado líquido. A TfClat forneceu valores entre 5,2 e 9,5 ${ }^{\circ} \mathrm{C}$ (Figura 15C). A Tht apresentou valores entre 144 e $448{ }^{\circ} \mathrm{C}$ (Figura 15E) e a homogeneização ocorreu tanto para o estado líquido quanto para vapor (Figura15F). Os resultados das análises no Tipo 3 forneceram valores de Tfg entre 0 e $-14,2{ }^{\circ} \mathrm{C}$ (Figura 15D), e não foi possível a observação da temperatura do eutético. A Tht ocorreu entre 104 a $387^{\circ} \mathrm{C}$ (Figura 15E), todas homogeneizaram para o estado líquido.

\section{Alvo Babi}

No alvo Babi, o Tipo 3 apresentou Tfg entre -0,4 e $-9,3^{\circ} \mathrm{C}$ (Figura 15D). A Tht revelou valores entre $136 \mathrm{e}$ $410^{\circ} \mathrm{C}$ (Figura15E), e todas as inclusões homogeneizaram para o estado líquido. Assim como no alvo Jerimum de Cima não foi possível visualizar a temperatura do eutético para o Tipo 3.

\section{DENSIDADE E COMPOSIÇÃO}

Quanto à densidade e à composição, as IF do Tipo 2 do alvo Jerimum de Cima apresentam densidade global entre 0,6 e 1,0 g/ $/ \mathrm{cm}^{3}$ e densidade do $\mathrm{CO}_{2}$ entre 0,4 e 0,7 g/ $\mathrm{cm}^{3}$. A salinidade para este alvo, com base nas temperaturas de fusão do clatrato em inclusões aquocarbônicas, revelou valores entre 1 e 7,8\% em peso equivalente de $\mathrm{NaCl}$. Os valores de $\mathrm{TfCO}_{2}$ nas IF do Tipo 2 indicam o $\mathrm{CO}_{2}$ como o principal componente volátil na fase carbônica, porém com presença menor de outros voláteis, como o $\mathrm{N}_{2}$ e/ou $\mathrm{CH}_{4}$. Usando a abordagem gráfica de van den Kerkhof \& Thiery (1994), estimam-se frações molares inferiores a 0,2 para esses compostos.

Tipo 3 tem densidade global entre 0,5 e $1 \mathrm{~g} / \mathrm{cm}^{3}$, com salinidade entre 0 e $18 \%$ em peso equivalente de $\mathrm{NaCl}$. Os Tipos 2 e 3 apresentam densidade com valores baixos a moderados, entre 0,4 e $0,7 \mathrm{~g} / \mathrm{cm}^{3}$ e 0,5 e $1 \mathrm{~g} / \mathrm{cm}^{3}$, respectivamente; assim como os valores de salinidade, entre 1 a $8,8 \%$ e 0 a $18 \%$ em peso equivalente de $\mathrm{NaCl}$, respectivamente.

No alvo Babi, a densidade para o Tipo 3 apresentou valores entre 0,5 e $1 \mathrm{~g} / \mathrm{cm}^{3}$, com salinidade entre 0,7 e $13,2 \%$, em peso equivalente de $\mathrm{NaCl}$. Assim como no alvo Jerimum de Cima estes valores são baixos a moderados.

\section{ORIGEM DAS INCLUSÕES FLUIDAS}

Para o alvo Jerimum de Cima, os dados microtermométricos e as características petrográficas das IF indicaram aprisionamento de três tipos de inclusões (carbônico, aquocarbônico e aquoso). As relações entre salinidade e temperatura de homogeneização final, quando os resultados são tomados em conjunto, mostram espalhamento dos dados e não são claras com relação a processos (i.e., tendências). Entretanto, abordando os resultados por meio do conceito de assembleias de inclusões fluidas (Fluid Inclusion Assemblage - FIA, Goldstein \& Reynolds, 1994; Chi \& Lu, 2008), isto é, grupos de inclusões fluidas espacialmente associadas e aprisionadas em um mesmo momento (em geral em grupos ou trilhas), a análise dos dados mostra-se mais consistente (Figura 16). As IF aquocarbônicas representam uma população homogênea quanto à salinidade, composição, densidade e forma de ocorrência, revelando coexistência espacial com IF carbônicas e aquosas (Figura 16). Essa pequena variação composicional e de densidade indica que se trata de um único fluido. 


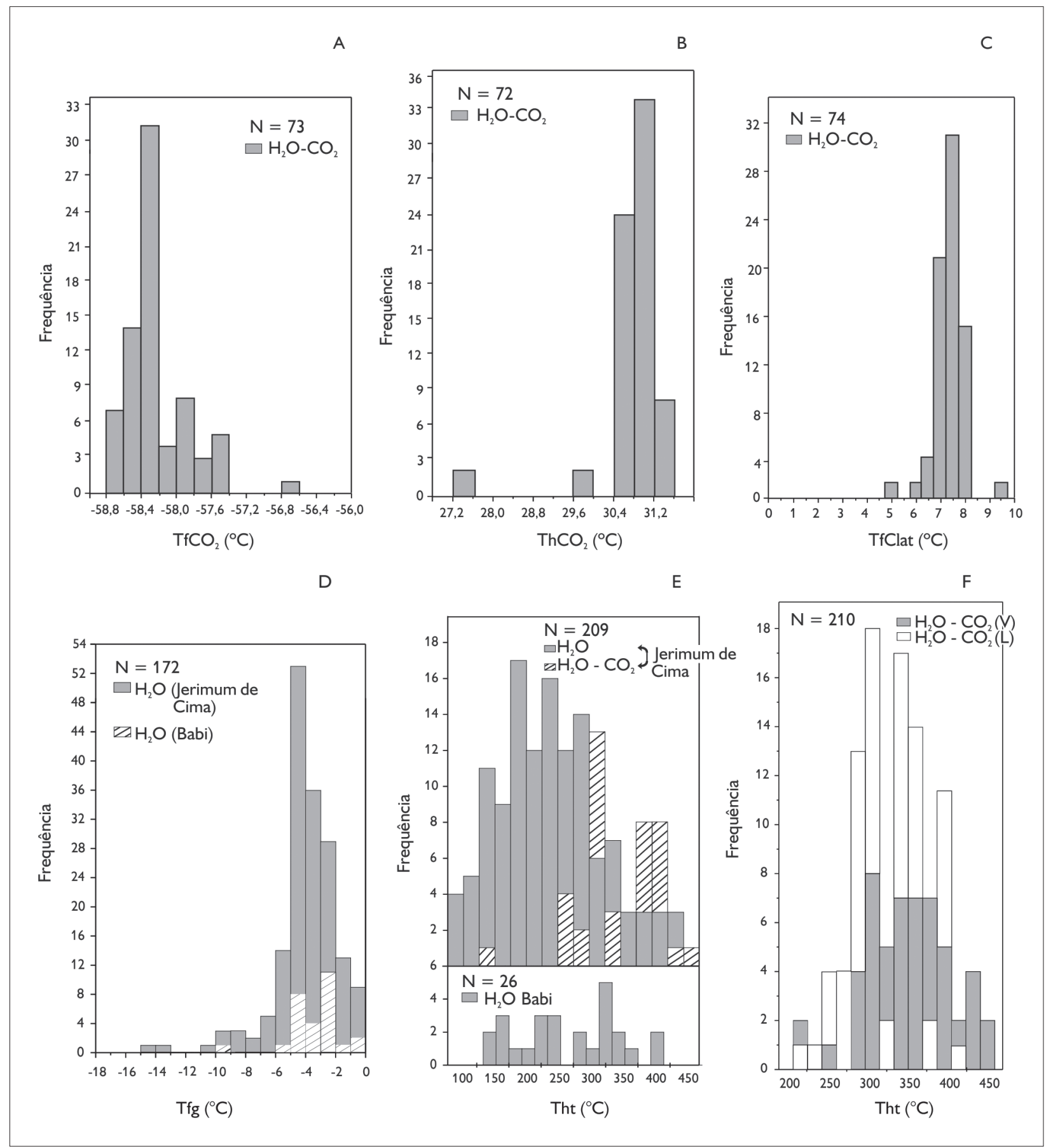

Figura 15. Histogramas com resultados das análises microtermométricas das inclusões fluidas dos alvos Jerimum de Cima e Babi. A) Temperatura de fusão do $\mathrm{CO}_{2}$ das inclusões fluidas do Tipo 2 do alvo Jerimum de Cima; $\mathrm{B}$ ) temperatura de homogeneização do $\mathrm{CO}_{2}$ das inclusões fluidas do Tipo 2 do Jerimum de Cima; C) temperatura de fusão do clatrato do Tipo 2 do alvo Jerimum de Cima; D) temperatura de fusão do gelo do Tipo 3 dos alvos Jerimum de Cima e Babi; E) temperatura de homogeneização total dos Tipos 2 e 3 do alvo Jerimum de Cima e do Tipo 3 do alvo Babi; F) temperatura de homogeneização total (fornecendo o estado físico para qual a inclusão se homogeneizou: $\vee=$ vapor, $L=$ líquido) do Tipo 2 do alvo Jerimum de Cima. 


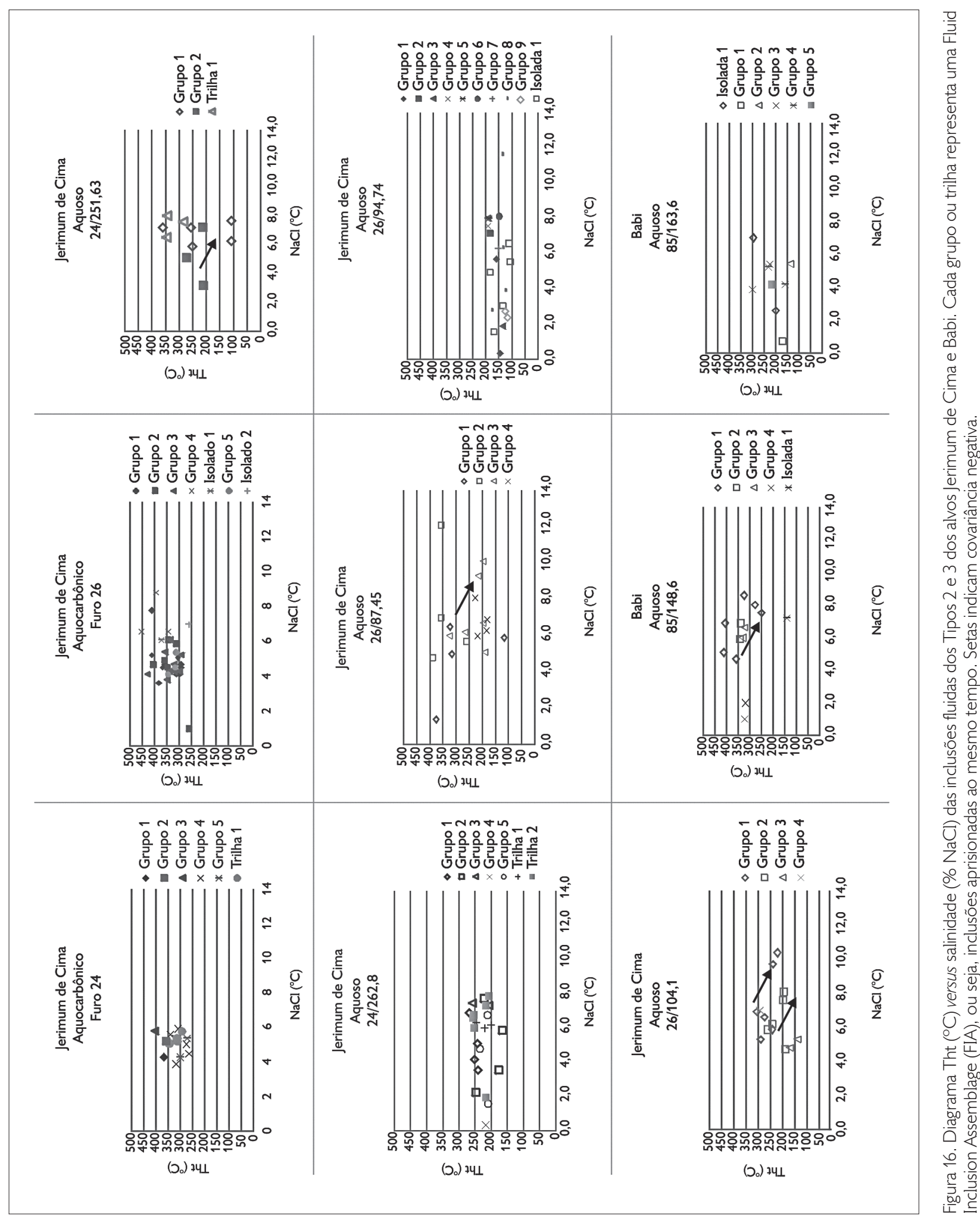


Por outro lado, estas IF (aquocarbônicas) mostraram grande variação em relação ao $\mathrm{VCO}_{2}$ e apresentaram homogeneização final tanto no estado líquido quanto no gasoso, em intervalo relativamente similar de temperatura. Essa variação se dá entre diferentes amostras, mas também em um mesmo campo microscópico e em um mesmo agrupamento ou trilha (FIA). Esses dados podem ser indicativos de imiscibilidade de fluidos (separação de fases). A correlação mostrada pela redução da fração molar de $\mathrm{NaCl}$ com aumento da fração molar de $\mathrm{CO}_{2}$ (Figura 17) corrobora a hipótese, e a variação de Tht em um mesmo grupamento ou trilha (FIA) pode ser explicada pelo aprisionamento de proporções variadas de fluido aquoso e carbônico e por flutuação nas condições de pressão. Parte das IF aquosas com Tht elevadas, no mesmo intervalo de Thte salinidade mostrado pelas IF aquocarbônicas (Figura 16), e que ocorrem em associação espacial com estas, podem representar parte desse fluido heterogêneo que não aprisionou $\mathrm{CO}_{2}$. A covariância negativa entre os valores de Tht e salinidade observada em várias FIA (Figura 16) também corrobora essa interpretação. Outra parte das inclusões aquosas do alvo Jerimum de Cima mostra salinidade e temperaturas baixas e a disposição horizontal nos diagramas Tht $x$ salinidade (Figura 16), em continuidade com as inclusões possivelmente geradas por separação de fases do fluido aquocarbônico, pode indicar mistura isotermal.

No alvo Babi, não há presença de inclusões carbônicas e aquocarbônicas, mas o Tipo 3 apresentou comportamento similar às do alvo Jerimum de Cima em relação entre salinidade e temperatura de homogeneização final (Figura 16). Assumindo a separação de fases discutida para o alvo Jerimum de Cima, é possível que o aprisionamento do fluido tenha sido mais tardio em Babi e apenas a fase aquosa foi aprisionada.

\section{ISÓTOPOS ESTÁVEIS}

A composição isotópica do oxigênio $(\mathrm{O})$, carbono $(\mathrm{C})$ e enxofre $(S)$ foi determinada nos seguintes minerais hidrotermais: quartzo, sericita, clorita, calcita, pirita e esfalerita. Esses minerais foram extraídos de veios (alteração

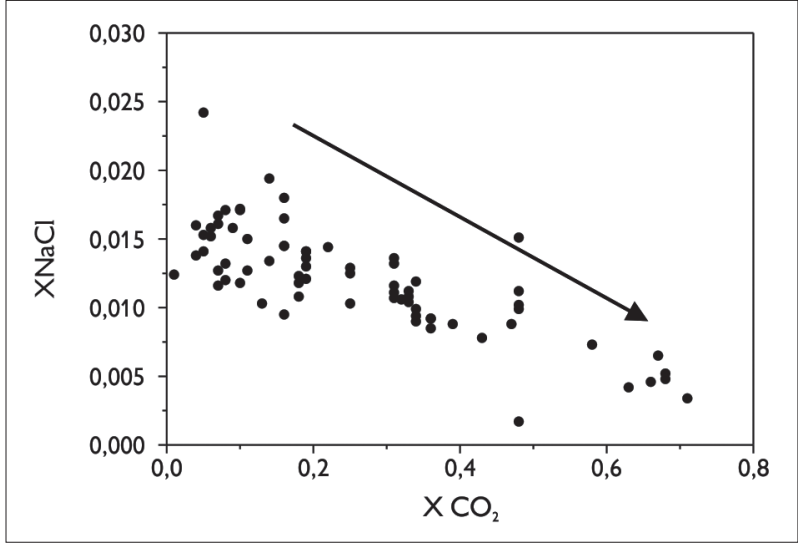

Figura 17. Diagrama $\mathrm{XNaCl}-\mathrm{XCO}_{2}$ das inclusões fluidas do Tipo 2 (aquocarbônicas) do alvo Jerimum de Cima, indicando redução da fração molar de $\mathrm{NaCl}$ com aumento da concentração de $\mathrm{CO}_{2}$.

fissural), agregados e da rocha com alteração disseminada. Também foram analisados concentrados de quartzo magmático na matriz da rocha não alterada. A galena só foi observada por meio do MEV, não sendo possível fazer separação mineral para analisar. Os resultados analíticos estão dispostos na Tabela 1.

\section{ALVO JERIMUM DE CIMA}

No alvo Jerimum de Cima, o quartzo magmático mostrou valores díspares de $+11,26$ e $+14,15 \%$. Os silicatos hidrotermais forneceram valores de $\delta^{18} \mathrm{O}$ de $+11,47$ a $+14,27 \%$ o para o quartzo de zona de alteração disseminada (agregado de silicificação), $+10,68$ a $+15,41 \%$ o para o quartzo de veio, $+10,37$ a $+10,81 \%$ o para a sericita disseminada e +9,78\%o para a única amostra de clorita da zona de alteração disseminada. A calcita forneceu valores de +9,37 a + 12,32\%o para a zona de alteração disseminada e $+8,18$ a $+9,69 \%$ o para os veios (Figura 18). Os valores de $\delta^{13} \mathrm{C}$ para a calcita disseminada variam de $-3,59$ a $-2,40 \%$ o e de -3,52 a -2,43\% o para a calcita extraída de veios. Os valores de $\delta^{34} S$ para a pirita disseminada variam predominantemente entre $+1,77$ e $+2,33 \%$ o (com um valor isolado de $+0,62 \%$ ) e na pirita do veio variam muito pouco, de $+1,40$ a $+1,73 \%$ o. O valor de $\delta^{34} \mathrm{~S}$ para a única amostra de esfalerita da zona de alteração disseminada é de $+1,47 \%$. 
Tabela 1. Composição dos isótopos de $\mathrm{O}, \mathrm{C}$ e S em minerais hidrotermais de veios e zonas de alteração disseminada nos alvos Jerimum de Cima e Babi.

(Continua)

\begin{tabular}{|c|c|c|c|c|c|}
\hline Amostra & Mineral & $\begin{array}{l}\text { Estágio ou estilo de } \\
\text { alteração }\end{array}$ & $\begin{array}{c}\delta^{18} \mathrm{O} \\
(\% \circ, \mathrm{SMOW})\end{array}$ & $\begin{array}{c}\delta^{13} \mathrm{C} \\
(\% \circ, \mathrm{PDB})\end{array}$ & $\begin{array}{c}\delta^{34} \mathrm{~S} \\
(\% \circ, \mathrm{CDT})\end{array}$ \\
\hline \multicolumn{6}{|c|}{ Jerimum de Cima } \\
\hline \multirow{4}{*}{$26 / 78,9$} & Quartzo & Veio & $+10,68$ & & \\
\hline & Pirita & Veio & & & $+1,71$ \\
\hline & Quartzo & Disseminado & $+11,47$ & & \\
\hline & Pirita & Disseminado & & & $+1,91$ \\
\hline \multirow{5}{*}{$26 / 81,7$} & Quartzo & Agregado & $+14,27$ & & \\
\hline & Quartzo & Veio & $+14,35$ & & \\
\hline & Pirita & Veio & & & $+1,95$ \\
\hline & Pirita & Disseminado & & & $+2,33$ \\
\hline & Esfalerita & Disseminado & & & $+1,47$ \\
\hline \multirow{4}{*}{$26 / 94,75$} & Pirita & Disseminado & & & $+1,77$ \\
\hline & Quartzo & Veio & $+15,41$ & & \\
\hline & Calcita & Veio & $+9,69$ & $-2,43$ & \\
\hline & Pirita & Veio & & & $+1,40$ \\
\hline \multirow{7}{*}{$26 / 97,4$} & Quartzo & Estágio magmático & $+11,26$ & & \\
\hline & Quartzo & Veio & $+13,35$ & & \\
\hline & Calcita & Veio & $+9,56$ & $-3,52$ & \\
\hline & Pirita & Veio & & & $+1,73$ \\
\hline & Sericita & Disseminado & $+10,81$ & & \\
\hline & Calcita & Disseminado & $+12,32$ & $-2,33$ & \\
\hline & Pirita & Disseminado & & & $+2,28$ \\
\hline \multirow{3}{*}{$26 / 99,8$} & Quartzo & Disseminado & $+11,99$ & & \\
\hline & Clorita & Disseminado & $+9,78$ & & \\
\hline & Calcita & Disseminado & $+9,37$ & $-3,59$ & \\
\hline \multirow{6}{*}{$24 / 262,80$} & Quartzo & Disseminado & $+14,19$ & & \\
\hline & Quartzo & Veio & $+14,15$ & & \\
\hline & Calcita & Veio & $+8,18$ & $-3,45$ & \\
\hline & Sericita & Disseminado & $+10,37$ & & \\
\hline & Calcita & Disseminado & $+9,62$ & $-2,40$ & \\
\hline & Pirita & Disseminado & & & $+0,62$ \\
\hline \multicolumn{6}{|c|}{ Babi } \\
\hline \multirow{3}{*}{$85 / 109,9$} & Sericita & Disseminado & $+10,14$ & & \\
\hline & Calcita & Disseminado & $+10,80$ & $-2,18$ & \\
\hline & Pirita & Disseminado & & & $+0,57$ \\
\hline $85 / 144,6$ & Quartzo & Veio & $+13,73$ & & \\
\hline
\end{tabular}

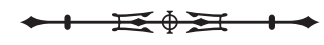


Tabela 1.

(Conclusão)

\begin{tabular}{|c|c|c|c|c|c|}
\hline Amostra & Mineral & $\begin{array}{l}\text { Estágio ou estilo de } \\
\text { alteração }\end{array}$ & $\begin{array}{c}\delta^{18} \mathrm{O} \\
(\% \circ, \mathrm{SMOW})\end{array}$ & $\begin{array}{c}\delta^{13} \mathrm{C} \\
(\%, \mathrm{PDB})\end{array}$ & $\begin{array}{c}\delta^{34} S \\
(\% \circ, C D T)\end{array}$ \\
\hline \multirow{3}{*}{$85 / 148,6$} & Quartzo & Disseminado & $+13,34$ & & \\
\hline & Calcita & Disseminado & $+12,27$ & $-2,17$ & \\
\hline & Quartzo & Veio & $+13,05$ & & \\
\hline \multirow{6}{*}{$85 / 149,6$} & Quartzo & Veio & $+13,53$ & & \\
\hline & Pirita & Veio & & & $+0,74$ \\
\hline & Quartzo & Disseminado & $+11,83$ & & \\
\hline & Clorita & Disseminado & $+9,85$ & & \\
\hline & Calcita & Disseminado & $+9,26$ & $-3,90$ & \\
\hline & Pirita & Disseminado & & & $+0,87$ \\
\hline \multirow{7}{*}{$85 / 163,6$} & Calcita & Veio & $+7,87$ & $-4,64$ & \\
\hline & Pirita & Veio & & & $+0,24$ \\
\hline & Quartzo & Disseminado & $+10,62$ & & \\
\hline & Sericita & Disseminado & $+9,05$ & & \\
\hline & Clorita & Disseminado & $+9,85$ & & \\
\hline & Calcita & Disseminado & $+11,92$ & $-2,95$ & \\
\hline & Pirita & Disseminado & & & $+0,97$ \\
\hline
\end{tabular}

\section{ALVO BABI}

$\bigcirc$ quartzo do alvo Babi forneceu valores de $\delta^{18} \mathrm{O}$ de $+10,62$ a $+13,34 \%$ onas zonas de alteração nas rochas hospedeiras e de $+13,05$ a $+13,73 \%$ o para o quartzo extraído de veios. Foram obtidos valores de $\delta^{18} \mathrm{O}$ de $+9,05$ a $+10,14 \%$ o para a sericita e $+9,85 \%$ o para a clorita disseminada, além de valores de $+9,26$ a $+12,27 \%$ o para a calcita disseminada e $+7,87 \%$ o para a calcita extraída de veio (Figura 18). Os valores de $\delta^{13} \mathrm{C}$ para a calcita da zona de alteração variam de $-3,90$ a -2,17\%o e são de -4,64\%。 para a calcita extraída do veio. Os valores de $\delta^{34} \mathrm{~S}$ para a pirita disseminada variam de $+0,57$ a $+0,97 \%$ e para a pirita de veio variam de $+0,24 \mathrm{a}+0,74 \%$.

\section{GEOTERMOMETRIA ISOTÓPICA}

Temperaturas foram calculadas para diversos pares minerais, usando equações de fracionamento isotópico adequadas e assumindo equilíbrio (petrográfico) na formação dos minerais. As temperaturas calculadas

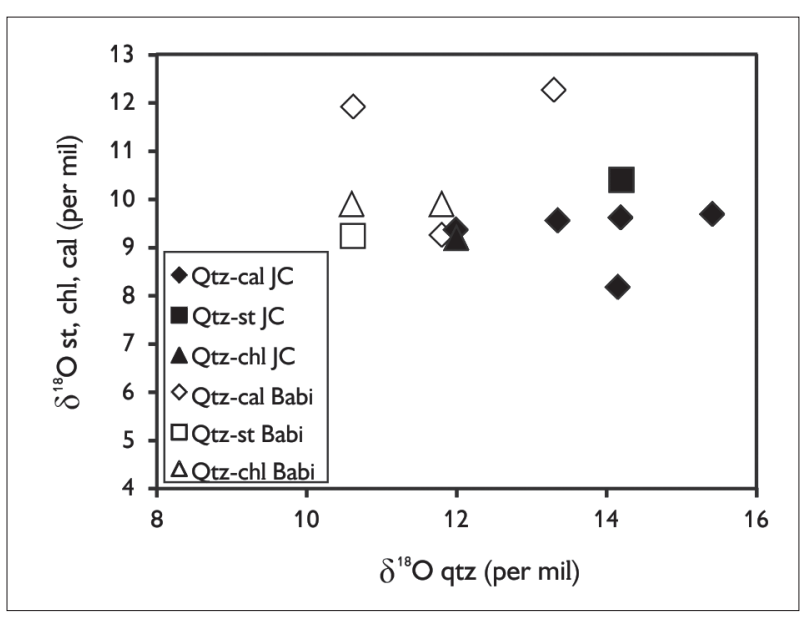

Figura 18. Diagrama que compara valores de $\delta^{18} \bigcirc$ do quartzo e dos minerais hidrotermais dos alvos Jerimum de Cima e Babi.

encontram-se na Tabela 2. Os resultados mostram três grupos de valores: (1) acima de $660{ }^{\circ} \mathrm{C}$, (2) entre 305 e $330^{\circ} \mathrm{C}$ para alteração disseminada e (3) entre 108 e 205 ${ }^{\circ} \mathrm{C}$ para alteração disseminada e em veio.

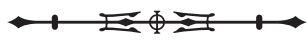


Os primeiros são valores superiores às temperaturas magmáticas e entende-se que não representam temperaturas de equilíbrio. Em geral, envolvem clorita e sericita e é provável que a composição isotópica desses minerais reflita substituição incompleta do mineral máfico ou feldspato original (por exemplo, Kontak et al., 2011). Os valores intermediários são condizentes com as temperaturas de homogeneização das inclusões fluidas aquocarbônicas e parte das aquosas, e podem ser considerados como geologicamente relevantes. Os últimos, todos obtidos em pares quartzo-calcita, são bastante variáveis, mas também compatíveis com temperaturas obtidas em inclusões fluidas aquosas.

\section{DISCUSSÕES}

\section{CAUSAS DAS VARIAÇÕES ISOTÓPICAS}

Em um sistema fechado, no qual minerais se formam a partir de um único fluido e em condições isotermais, as variações na composição isotópica dos minerais coexistentes devem ser mínimas (Sheppard, 1986). Não é isso que se observa neste estudo, mesmo para um mesmo tipo ou estágio de alteração (veios e disseminada). Variações isotópicas significativas dentro de um sistema hidrotermal são mais comumente advindas de: (1) variação na temperatura de precipitação (diferentes estágios), (2) variação na composição do fluido (mistura), (3) desequilíbrio (alteração posterior à cristalização) ou (4) combinação desses fatores. Efetivamente, a sequência de alteração disseminada/ pervasiva seguida de fissural/venular foi documentada neste estudo, assim como presença de fluidos com diferentes composições e temperaturas de aprisionamento.

Os valores de $\delta^{18} \mathrm{O}$ do quartzo mostram-se bastante variáveis nos veios e observa-se uma concentração de valores em torno de +11 e $+14,5 \%$. Já os de $\delta^{18} \mathrm{O}$ e $\delta^{13} \mathrm{C}$ da calcita mostram-se variáveis entre diferentes amostras, mas com boa correlação positiva em Babi e fraca em Jerimum de Cima (Figura 18). Essa boa correlação pode indicar, segundo Zheng \& Hoefs (1993), precipitação de
Tabela 2. Temperaturas calculadas a partir do fracionamento isotópico entre minerais hidrotermais. Legenda: $*$ = valores entre parênteses não representam equilíbrio. Para os demais, ver discussão no texto. Equações de fracionamento: quartzo-muscovita e muscovita-calcita (Chacko et al., 1996); quartzo-clorita (Zheng, 1993); quartzo-calcita (Sharp \& Kirschner, 1994); pirita-esfalerita (Ohmoto \& Rye, 1979). Abreviaturas: qtz = quartzo, st $=$ sericita, $\mathrm{chl}=$ clorita, $\mathrm{cal}=$ calcita, py $=$ pirita, $\mathrm{sp}=$ esfalerita.

\begin{tabular}{c|c|c|c}
\hline \multicolumn{4}{c|}{ Jerimum de Cima } \\
\hline $24 / 262,80$ & Disseminada & qtz-st & 330 \\
\hline $26 / 99,8$ & Disseminada & qtz-chl & $(664)$ \\
\hline $24 / 262,80$ & Disseminada & qtz-cal & 162 \\
\hline $24 / 262,80$ & Veio & qtz-cal & 108 \\
\hline $26 / 94,75$ & Veio & qtz-cal & 118 \\
\hline $26 / 97,4$ & Veio & qtz-cal & 205 \\
\hline $26 / 99,8$ & Disseminada & qtz-cal & 305 \\
\hline $26 / 81,7$ & Disseminada & py-sp & 318 \\
\hline \multicolumn{4}{|c|}{ Babi } \\
\hline $85 / 163,6$ & Disseminada & qtz-st & $(680)$ \\
\hline $85 / 149,6$ & Disseminada & qtz-chl & $(889)$ \\
\hline $85 / 163,6$ & Disseminada & qtz-chl & $(1474)$ \\
\hline $85 / 148,6$ & Disseminada & qtz-cal & $(660)$ \\
\hline $85 / 149,6$ & Disseminada & qtz-cal & 317 \\
\hline $85 / 109,9$ & Disseminada & st-cal & $(900)$ \\
\hline & &
\end{tabular}

calcita por mistura de fluidos com diferente salinidade ou por fluido que contém $\mathrm{HCO}_{3}$ - devido a efeito de temperatura associado com desgaseificação de $\mathrm{CO}_{2}$ ou interação fluido-rocha. Observa-se na Figura 18 que há uma variação significativa dos valores de $\delta^{18} \bigcirc$ do quartzo, sem correspondente variação nos valores de $\delta^{18} \bigcirc$ da calcita. Isso pode resultar de mistura de fluidos, ou deposição em temperaturas diferentes (vários estágios), ou ausência de equilíbrio. $\bigcirc$ estudo de inclusões fluidas não indica mistura de fluidos em Babi, nem presença de inclusões portadoras de $\mathrm{CO}_{2}$ nesse alvo. Portanto, é provável que a calcita tenha se depositado em um estágio distinto do quartzo ou que tenha sido afetada por alteração secundária, provocada por fluido aquoso (desprovido de $\mathrm{CO}_{2}$ - de modo que só o oxigênio foi afetado). 


\section{TEMPERATURA E PRESSÃO DA ALTERAÇÃO HIDROTERMAL E DA MINERALIZAÇÃO}

Para se determinar as condições de pressão e temperatura da alteração hidrotermal e/ou mineralização nos dois alvos, foram usados os dados de temperatura de homogeneização das inclusões fluidas e as temperaturas obtidas por termometria isotópica. Isócoras calculadas para os fluidos aquocarbônicos e/ou aquosos e para o intervalo de variação de densidades desses fluidos estão representadas nas Figuras 19 (Jerimum de Cima) e 20 (Babi).

Para o alvo Jerimum de Cima, a Figura 19 mostra que isócoras dos diferentes tipos (aquocarbônicas e aquosas) não se cruzam no espaço P-T. Isso quer dizer que não evidenciam mistura de fluidos, ou que, se houve mistura, os fluidos evoluíram em trajetórias paralelas de P-T (não há contraste significativo de densidade). É digno de nota que o intervalo de temperatura obtido por geotermometria isotópica (318$330{ }^{\circ} \mathrm{C}$ ) é coincidente com valores de temperatura de homogeneização total das inclusões aquocarbônicas e que as isócoras dessas inclusões seccionam o solvus do sistema $\mathrm{H}_{2} \mathrm{O}-\mathrm{CO}_{2}-\mathrm{NaCl}$ nesse mesmo intervalo de temperatura. Esses fatos, aliados à associação entre mineralização e sulfetação e à ocorrência de separação de fases, indicam que as temperaturas obtidas representam o estágio de alteração hidrotermal disseminada e, em consequência, a mineralização. As temperaturas de homogeneização das inclusões fluidas aquocarbônicas, dominantemente no intervalo $300-400{ }^{\circ} \mathrm{C}$, indicam que a alteração venular formou-se em intervalo de temperatura similar ao da alteração disseminada. Assim, a mineralização em Jerimum de Cima ocorreu no intervalo de 318 a $330^{\circ} \mathrm{C}$ e 1,3 a 2,0 kbar, a partir de fluidos originalmente aquocarbônicos. A presença de inclusões aquosas de mais baixa temperatura (100-250 ${ }^{\circ} \mathrm{C}$ ) e as temperaturas obtidas pelos pares quartzocalcita $\left(108-205^{\circ} \mathrm{C}\right)$ indicam que a carbonatação se deu em temperatura inferior. Não há certeza, entretanto, se essas são temperaturas de equilíbrio, já que são bastante variáveis.

No alvo Babi, as alterações disseminada e venular ocorreram em condições similares às do alvo Jerimum de

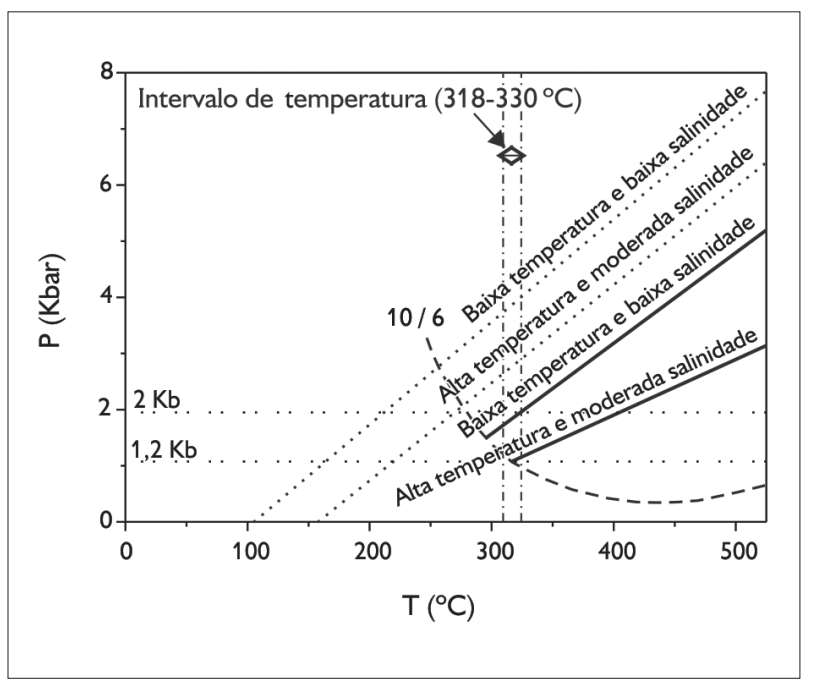

Figura 19. Diagrama Pressão (Kbar) - Temperatura $\left({ }^{\circ} \mathrm{C}\right)$ para inclusões fluidas dos Tipos 2 e 3 do alvo Jerimum de Cima. A curva tracejada representa o solvus do sistema $\mathrm{H}_{2} \mathrm{O}-\mathrm{CO}_{2}-\mathrm{NaCl}$ com 10 mol\% $\mathrm{CO}_{2}$ e $6 \%$ de $\mathrm{NaCl}$ (Bowers \& Helgeson, 1983). As isócoras pontilhadas representam o fluido aquoso e as isócoras de linhas cheias representam o fluido aquocarbônico. As linhas verticais delimitam o intervalo de temperatura obtido pela termometria isotópica (Tabela 2).

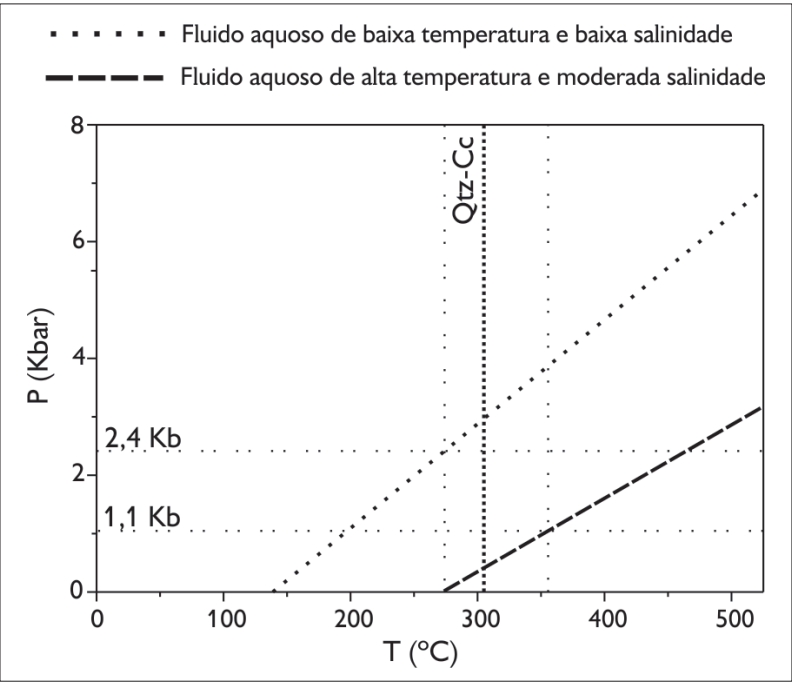

Figura 20. Diagrama Pressão (Kbar) - Temperatura $\left({ }^{\circ} \mathrm{C}\right)$ das inclusões fluidas do Tipo 3 do alvo Babi. A linha vertical pontilhada representa a temperatura obtida pelo par quartzo - calcita por isótopos estáveis.

Cima, conforme a termometria isotópica e homogeneização final das inclusões aquosas (Figura 16), embora apenas o fluido aquoso tenha sido registrado em Babi.

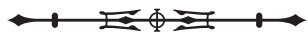




\section{COMPOSIÇÃO E FONTE DOS FLUIDOS}

A composição isotópica dos minerais hidrotermais em equilíbrio com fluido foi calculada para intervalos de temperatura de 330 a $318^{\circ} \mathrm{C}$ para os silicatos e de 305 a $205{ }^{\circ} \mathrm{C}$ para a calcita, conforme os dados petrográficos, da termometria isotópica e homogeneização de inclusões fluidas. Os resultados são apresentados na Tabela 3, juntamente com as equações de fracionamento mineral$\mathrm{H}_{2} \mathrm{O}$ utilizadas no cálculo.

No alvo Jerimum de Cima, os valores de $\delta^{18} \mathrm{O}_{\mathrm{H} 2 \mathrm{O}}$ mostram variação expressiva, de +4,4 a +8,3\% no quartzo de veios. Valores menos variáveis, mas dentro desse mesmo intervalo, foram calculados para quartzo, sericita e clorita da alteração disseminada. Variação desse porte para o estreito intervalo de temperatura utilizado requer fluidos variados (mistura) ou evolução na composição do fluido. Evidências de mistura podem ser indicadas pelas inclusões fluidas aquosas, que mostram variação de temperatura de homogeneização e salinidade em uma mesma assembleia de inclusões (FIA, Figura 16). Valores acima de $+5,5 \%$ o são compatíveis com derivação magmática ou metamórfica. Não dispomos de valores de $\delta D_{\mathrm{H}_{2} \mathrm{O}}$ para uma melhor definição, mas a ausência de evento metamórfico na época atribuída para a mineralização (Assunção \& Klein, 2014; Silva Júnior et al., 2015) favorece derivação magmática. Valores inferiores a $+5,5 \%$, dada a evidência de mistura com fluido de baixa temperatura e baixa salinidade, indica participação de fluido meteórico (Figura 16). Os baixos valores de $\delta^{18} \mathrm{O}_{\mathrm{H} 2 \mathrm{O}}$ calculados a partir da calcita corroboram maior participação de água meteórica em estágios mais tardios de alteração.

Os valores de $\delta^{13} \mathrm{C}$ do $\mathrm{CO}_{2}$ do fluido calculado para a calcita disseminada variam de $-0,3$ a $-1,5 \% \circ\left(305^{\circ} \mathrm{C}\right)$ e de $-2,1$ a $-3,2 \% \circ\left(205^{\circ} \mathrm{C}\right)$ para calcita de veio no alvo Jerimum de Cima; e -0,1 a -1,8\%o $\left(305^{\circ} \mathrm{C}\right)$ e -4,3\%o (205 $\left.{ }^{\circ} \mathrm{C}\right)$ para calcita disseminada e de veio, respectivamente, no alvo Babi. Os valores mais negativos são de difícil interpretação, pois coincidem com os valores do carbono magmático, metamórfico e sedimentar, enquanto os valores mais elevados se aproximam dos carbonatos marinhos (Ohmoto \& Rye, 1979). Carbonatos marinhos não são conhecidos na Província Tapajós, de forma que essa fonte

Tabela 3. Composição isotópica do oxigênio do fluido $\left(\delta^{18} \mathrm{O} \mathrm{H}_{2} \mathrm{O}\right.$, \%० SMOW) em equilíbrio com minerais hidrotermais, calculado para diferentes temperaturas. Legenda: * = equações de fracionamento isotópico: Quartzo- $\mathrm{H}_{2} \mathrm{O}$ (Matsuhisa et al., 1979), Muscovita- $\mathrm{H}_{2} \mathrm{O}$ (O’Neil \& Taylor, 1969), Clorita- $\mathrm{H}_{2} \mathrm{O}$ (Wenner \& Taylor Jr., 1971), Calcita- $\mathrm{H}_{2} \mathrm{O}$ (Friedman \& O'Neil, 1977).

\begin{tabular}{|c|c|c|c|c|c|c|}
\hline Depósito & Estilo de alteração & Mineral- $\mathrm{H}_{2} \mathrm{O}^{*}$ & $330^{\circ} \mathrm{C}$ & $318^{\circ} \mathrm{C}$ & $305^{\circ} \mathrm{C}$ & $205^{\circ} \mathrm{C}$ \\
\hline \multirow{6}{*}{$\begin{array}{l}\text { Jerimum de } \\
\text { Cima }\end{array}$} & Veio/agregado & Quartzo & $+4,8 a+8,3$ & $+4,4 a+7,9$ & - & - \\
\hline & Disseminada & Quartzo & $+5,5$ & $+5,2$ & - & - \\
\hline & Disseminada & Sericita & $+8,2$ & $+7,7$ & - & - \\
\hline & Disseminada & Clorita & $+9,6$ & $+9,4$ & - & - \\
\hline & Disseminada & Calcita & $+4,6 a+7,5$ & $+4,2 a+7,2$ & $+4,2 a+6,9$ & $+0,1 \mathrm{a}+3,0$ \\
\hline & Veio & Calcita & $+3,4 a+4,8$ & $+3,1 \mathrm{a}+4,7$ & $+2,7 a+4,1$ & $-1,1 a+0,4$ \\
\hline \multirow{6}{*}{ Babi } & Veio & Quartzo & $+4,8 a+7,9$ & $+4,4 a+7,5$ & - & - \\
\hline & Disseminada & Quartzo & $+6,0 a+7,5$ & $+5,6 a+7,1$ & - & - \\
\hline & Disseminada & Sericita & $+6,4 a+7,5$ & $+6,1 a+7,2$ & - & - \\
\hline & Disseminada & Clorita & $+10,3$ & $+10,1$ & - & - \\
\hline & Disseminada & Calcita & $+4,4 a+7,4$ & $+4,1 \mathrm{a}+7,1$ & $+4,2 \mathrm{a}+7,2$ & $0,0 a+3,0$ \\
\hline & Veio & Calcita & $+3,0$ & $+2,7$ & $+2,8$ & $-1,4$ \\
\hline
\end{tabular}

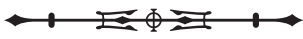


pode ser descartada, assim como a já citada ausência de metamorfismo sugere a não derivação a partir de fluido metamórfico. Portanto, carbono magmático ( \pm mantélico) parece ser a fonte mais provável para o $\mathrm{CO}_{2}$. Eventual desvio da composição magmática original pode ser derivado de mistura de fluidos, o que parece ter acontecido nos alvos estudados, e precipitação de calcita por fluido composto por $\mathrm{HCO}_{3}^{-}$, em processo associado com desgaseificação de $\mathrm{CO}_{2}$ a partir de magma ou interação fluido-rocha (Zheng \& Hoefs, 1993), o que é corroborado pela covariância positiva entre os valores de $\delta^{13} \mathrm{C}$ e $\delta^{18} \mathrm{O}$ da calcita.

Os valores de $\delta^{34} S$ do fluido sulfetado $\left(\mathrm{H}_{2} \mathrm{~S}\right)$, nas condições físico-químicas e mineralógicas descritas para Jerimum de Cima e Babi, são próximos dos valores de $\delta^{34} \mathrm{~S}$ medidos nos sulfetos (Ohmoto \& Rye, 1979). Esses valores (+1,4 a +1,7\%o em Jerimum de Cima, 0,2 a 0,9\%० em Babi) são compatíveis com enxofre de derivação magmática, direta ou por lixiviação de sulfetos de rochas ígneas (Ohmoto \& Rye, 1979).

\section{COMPARAÇÃO ENTRE JERIMUM DE CIMA E BABI E OUTROS DEPÓSITOS DO CAMPO MINERALIZADO DO CUIÚ-CUIÚ}

Um estudo comparativo entre os alvos Jerimum de Cima e Babi é de fundamental importância para entender os diferentes processos para a formação destes depósitos. Em relação à alteração hidrotermal, nos dois alvos ocorreram de forma fissural, por vezes pervasiva seletiva (disseminada). A principal diferença é em relação à sulfetação, que é mais expressiva no Jerimum de Cima. No entanto, em relação à assembleia mineralógica é bem semelhante nos dois alvos, com ocorrência de pirita, esfalerita, calcopirita e, raramente, galena. Sericitização e silicificação ocorrem mais expressivamente no Jerimum de Cima, enquanto em relação à cloritização e à carbonatação não foram observadas diferenças na ocorrência nos dois alvos, sendo quase igual. Estas informações vão de encontro aos dados obtidos por Assunção \& Klein (2014) e Araújo (2014), nos depósitos Moreira Gomes e Central, respectivamente. No entanto, Assunção \& Klein (2014) identificaram ocorrência de epidotização no depósito Moreira Gomes. No alvo Jerimum de Cima, foram identificados três tipos de IF (carbônico, aquocarbônico e aquoso); no Babi, apenas um foi identificado (aquoso), indicando ausência de $\mathrm{CO}_{2}$. IF aquosa do Jerimum de Cima indicou maiores salinidades, de 0 a $18 \%$, enquanto no alvo Babi está entre 0,7 a 13\%. Em relação à temperatura de homogeneização, os dois alvos apresentaram valores semelhantes, 105 a $410{ }^{\circ} \mathrm{C}$. Segundo Araújo (2014), no depósito Central foram aprisionados três tipos de IF (carbônico, aquocarbônico e aquoso) nas zonas menos afetadas pela deformação, com os fluidos que contêm $\mathrm{CO}_{2}$ apresentando salinidade de 2,42 a 11,15\% e temperatura de homogeneização de $340{ }^{\circ} \mathrm{C}$. Para o alvo Moreira Gomes, Assunção \& Klein (2014) definiram três tipos de IF (carbônico, aquocarbônico e aquoso). O fluido contendo $\mathrm{CO}_{2}$ para este depósito apresentou valores de salinidade de 1,6 a 11,8\% e temperatura de homogeneização de 280 a $350{ }^{\circ} \mathrm{C}$ e, para o fluido aquoso, a salinidade apresentou valores entre 0 e 10,1\% e temperatura de homogeneização entre 120 e $220^{\circ} \mathrm{C}$. Temperaturas foram calculadas para diversos pares minerais nos dois alvos, usando equações de fracionamento isotópico adequadas e assumindo equilíbrio (petrográfico) na formação dos minerais. Os resultados mostram três grupos de valores: (1) acima de $660{ }^{\circ} \mathrm{C}$, (2) entre 305 e $330^{\circ} \mathrm{C}$ e (3) entre 108 e $205^{\circ} \mathrm{C}$. No alvo Jerimum de Cima, pares quartzo-sericita, quartzo-calcita e pirita-esfalerita indicaram temperaturas de, respectivamente, $330^{\circ} \mathrm{C}, 305^{\circ} \mathrm{Ce} 318^{\circ} \mathrm{C}$. Par quatzo-calcita do alvo Babi forneceu temperatura de 317 ${ }^{\circ} \mathrm{C}$. Assunção \& Klein (2014) calcularam temperaturas para o depósito Moreira Gomes usando composição isotópica de oxigênio para os pares quartzo-calcita e quartzo-clorita, fornecendo valores entre 233 e $240^{\circ} \mathrm{C}$ (furo cc50), $317^{\circ} \mathrm{C}$ (furo cc58) e $356^{\circ} \mathrm{C}$ (furo cc69) para o par quartzo-calcita, e 304 a $359^{\circ} \mathrm{C}$ (furo cc58) para o par quartzo-clorita. Para o depósito Central, Araújo (2014) calculou apenas um par, quartzo-calcita, produzindo temperatura de $545^{\circ} \mathrm{C}$, porém este valor é muito elevado, não devendo, portanto, representar temperatura de equilíbrio. 


\section{MODELO GENÉTICO}

Vários modelos metalogenéticos já foram apontados para o campo aurífero da Província Aurífera do Tapajós, incluindo orogênico (Klein et al., 2001, 2004; Santos et al., 2001; Coutinho, 2008; Veloso \& Santos, 2013), relacionado a intrusões graníticas (Santos et al., 2001; Borges et al., 2009; Santiago et al., 2013; Villas et al., 2013; Assunção \& Klein, 2014), pórfiro (Jacobi, 1999; Juliani et al., 2002; EcheverriMisas et al., 2013) e epitermal (Dreher et al., 1998; Juliani et al., 2005). Para o campo mineralizado Cuiú-Cuiú, Coutinho (2008) advoga a classe dos depósitos orogênicos, o que foi contestado por Assunção \& Klein (2014) e Araújo (2014). O depósito Moreira Gomes hospeda-se em tonalitos da Suíte Intrusiva Creporizão, cuja idade de 1997 22 Ma foi obtida por evaporação de zircão por Silva Júnior et al. (2015). A idade da mineralização foi estimada em 1,86 Ga (Assunção \& Klein, 2014; Silva Júnior et al., 2015). O depósito Central apresenta características bem similares às de Moreira Gomes (Araújo, 2014). Assunção \& Klein (2014) admitem uma origem magmático-hidrotermal para o depósito Moreira Gomes, embora afirmem que este depósito não apresenta feições clássicas de depósitos relacionados a intrusões graníticas, tanto reduzidas quanto oxidadas, como salinidade, mineralogia hidrotermal, zoneamento de alterações e relação clara com intrusão causadora do sistema hidrotermal. A despeito disso, o modelo magmático-hidrotermal (relacionado com intrusão, por exemplo, Baker, 2002) foi preferido, em razão da ausência de episódio metamórfico conhecido à época da mineralização.

O depósito Jerimum de Cima apresenta similaridade com o depósito Central, no que concerne a: maior quantidade de inclusões fluidas aquosas em relação às aquocarbônicas; estilo da alteração hidrotermal, dominantemente fissural; e, sobretudo, ausência de metamorfismo relacionado à época estimada para a gênese do depósito Jerimum de Cima que fosse capaz de produzir os fluidos metamórficos envolvidos na formação de depósitos orogênicos. Em um sistema magmáticohidrotermal, aqui proposto, exsolução do fluido pelo magma levou ao consumo do $\mathrm{CO}_{2}$ aprisionado nas fases mais precoces, pois $\mathrm{O} \mathrm{CO}_{2}$ tem menor solubilidade em magmas silicáticos do que a $\mathrm{H}_{2} \mathrm{O}$ (Baker, 2002), predominando, assim, as inclusões aquosas. Isso pode explicar a ausência de inclusões fluidas aquocarbônicas no alvo Babi, sendo uns dos responsáveis pela fraca mineralização neste alvo, juntamente com a fraca ação de deformação que origina canais para o transporte do fluido mineralizador. O sistema provável adotado por este autor nos dois alvos é o magmático-hidrotermal (relacionado à intrusão?), com mistura de fluido magmático e meteórico pode ser inferido para estes alvos.

\section{CONSIDERAÇÕES FINAIS}

As rochas hospedeiras nos alvos Jerimum de Cima e Babi estão relacionadas com o Complexo Cuiú-Cuiú em mapas recentes (Moura et al., 2014). Contudo, suas características petrográficas (granitoides pouco ou não deformados, ausência de gnaisses) sugerem que possivelmente estejam relacionadas a magmatismo mais jovem, como os das suítes intrusivas Creporizão ou Parauari. Idades modelo Pb-Pb em sulfetos nos depósitos Moreira Gomes e Central e no alvo Pau da Merenda (Silva Júnior et al., 2015) indicam que a mineralização pode ter relação com a evolução magmática da Suíte Intrusiva Parauari, o que é extrapolado para este estudo, visto o provável caráter magmático-hidrotermal da mineralização em Jerimum de Cima e Babi.

Com os estudos petrográficos, inclusões fluidas e isótopos estáveis, pode-se concluir que: a intensa alteração hidrotermal ocorre no alvo Jerimum de Cima sericitização, silicificação e sulfetação; com a variação dos valores de Tht nos tipos de IF pode-se afirmar a presença de fluidos distintos no alvo Jerimum de Cima; no entanto, o fluido aquoso pode ser o mesmo para os dois alvos, devido a Tht ser bem próxima; os dois alvos apresentam variações expressivas nos valores de $\delta^{18} \mathrm{O}_{\text {SMOW }}$ nos silicatos (7,9 a 15,4\%o), indicando mais de uma fonte de fluido, ou variação na temperatura de precipitação; a baixa variação nos valores $\delta^{13} C_{P D B}$ nos dois alvos pode indicar 
um reservatório homogêneo para o carbono incorporado na calcita e/ou precipitação em temperatura similar; tipos de fluidos e os valores isotópicos são compatíveis com derivação magmática ou metamórfica; a menor proporção de fluidos aquocarbônicos em Babi pode explicar a mineralização incipiente nesse alvo; provável sistema magmático-hidrotermal (relacionado à intrusão?), com mistura de fluido magmático e meteórico.

\section{AGRADECIMENTOS}

Os autores agradecem a Dennis Moore (Magellan Minerals) pelo acesso à área do projeto Cuiú-Cuiú e pela cessão de dados e testemunhos de sondagem. CASSJr agradece ao Conselho Nacional de Desenvolvimento Científico e Tecnológico (CNPq) pela concessão de bolsa de estudos (processo 133935/2013-2). ELK agradece ao CNPq pela concessão de bolsa de produtividade em pesquisa (processo 306723/2009-3) e apoio financeiro (processo 475614/20100 - Projeto "Metalogênese do campo mineralizado do Cuiú-Cuiú, Província Aurífera do Tapajós, Estado do Pará"). Contribuição ao Instituto Nacional de Ciência e Tecnologia de Geociências da Amazônia (INCT/GEOCIAM).

\section{REFERÊNCIAS}

ARAÚJO, A. C. S., 2014. Estudos isotópicos e de inclusões fluidas no depósito central do campo mineralizado do CuiúCuiú, Província Aurífera do Tapajós, Estado do Pará: 1-62. Dissertação (Mestrado em Geociências) - Universidade Federal do Pará, Belém. Disponível em: < http://repositorio.ufpa.br/jspui/ handle/2011/6367>. Acesso em: 19 junho 2015.

ASSUNÇÃO, R. F. S. \& E. L. KLEIN, 2014. The Moreira Gomes deposit of the Cuiú-Cuiú goldfield: fluid inclusions and stable isotope constraints and implications for the genesis of granitehosted gold mineralization in the Tapajós Gold Province, Brazil. Journal of South American Earth Sciences 49: 85-105.

BAHIA, R. B. C. \& M. L. E. S. QUADROS, 2000. Geologia e recursos minerais da folha Caracol: folha SB.21-X-C: estado do Pará. Escala 1:250.000: 1 CD-ROM. CPRM (Projeto Levantamentos Geológicos Básicos do Brasil; Projeto Especial Província Mineral do Tapajós - PROMIN Tapajós), Brasília.

BAKER, T., 2002. Emplacement depth and carbon dioxide-rich fluid inclusions in intrusion-related gold deposits. Economic Geology 97(5): 1111-1117.
BORGES, R. M. K., R. DALL'AGNOL, C. N. LAMARÃO, M. A. B. M. FIGUEIREDO, A. A. S. LEITE, C. E. M. BARROS \& H. T. COSTI, 2009. Petrografia, química mineral e processos hidrotermais associados ao depósito de ouro São Jorge, Província Aurífera do Tapajós, Cráton Amazônico. Revista Brasileira de Geociências 39(2): 375-393.

BOWERS, T. S. \& H. C. HELGESON, 1983. Calculation of the thermodynamic and geochemical consequences of nonideal mixing in the system $\mathrm{H}_{2} \mathrm{O}-\mathrm{CO}_{2}-\mathrm{NaCl}$ on phase relations in geological systems: equation of state for $\mathrm{H}_{2} \mathrm{O}-\mathrm{CO}_{2}-\mathrm{NaCl}$ fluids at high pressures and temperatures. Geochimica et Cosmochimica Acta 47(7): 1247-1275.

BROWN, P. E., 1989. Flincor: a microcomputer program for the reduction and investigation of fluid-inclusion data. American Mineralogist 74: 1390-1393.

BROWN, P. E. \& W. M. LAMB, 1986. Mixing of $\mathrm{H}_{2} \mathrm{O}-\mathrm{CO}_{2}$ in fluid inclusions: geobarometry and Archean gold deposits. Geochimica et Cosmochimica Acta 50(5): 847-852.

CHACKO, T., T. K. MAYEDA, R. N. CLAYTON \& J. R. GOLDSMITH, 1996. Oxygen isotope fractionations between $\mathrm{CO}_{2}$ and calcite. Geochimica et Cosmochimica Acta 55: $2867-2882$

CHI, G. X. \& H. Z. LU, 2008. Validation and representation of fluid inclusion microthermometric data using the fluid inclusion assemblage (FIA) concept. Acta Petrologica Sinica 24(9): 19451953.

COLLINS, P. L. F., 1979. Gas hydrates in $\mathrm{CO}_{2}$-bearing fluid inclusions and the use of freezing data for estimation of salinity. Economic Geology 74(6): 1435-1444.

COUTINHO, M. G. N., 2008. Província Mineral do Tapajós: geologia, metalogenia e mapa previsional para ouro em SIG: 1-420. CPRM, Rio de Janeiro.

DREHER, A. M., S. R. F. VLACH \& S. L. MARTINI, 1998. Adularia associated with epithermal gold veins in the Tapajós Mineral Province, Pará State, northern Brazil. Revista Brasileira de Geociências 28(3): 397-404.

ECHEVERRI-MISAS, C. M., C. JULIANI, L. V. S. MONTEIRO \& C. M. D. FERNANDES, 2013. Mineralização de Au-Cu do tipo pórfiro na Província Aurífera do Tapajós: implicações metalogenéticas. Simpósio Brasileiro de Metalogenia 3: 1 CD-ROM

FERREIRA, A. L., G. J. RIZZOTTO, M. E. L. S. QUADROS, R. B. C. BAHIA \& M. A. OLIVEIRA, 2004. Folha SB.21 - Tapajós. In: C. SCHOBBENHAUS, J. H. GONÇALVES, J. O. S. SANTOS, M. B. ABRAM, R. LEÃO NETO, G. M. M. MATOS, R. M. VIDOTTI, M. A. B. RAMOS \& J. D. A. JESUS (Ed.): Carta geológica do Brasil ao milionésimo: Sistema de Informações Geográficas-SIG: 1 CD-ROM. CPRM, Brasília. 
FRIEDMAN, I. \& J. R. O'NEIL, 1977. Data of Geochemistry: compilation of stable isotope fractionation factors of geochemical interest. U.S. Government Printing Office, (Geological Survey Professional Paper, 440-KK), Washington.

GOLDSTEIN, R. H. \& T. J. REYNOLDS, 1994. Systematics of fluid inclusions in diagenetic minerals: 1-199. Society for Sedimentary Geology (SEPM Short Course 31), Tulsa.

JACOBI, P., 1999. The discovery of epithermal Au-Cu-Mo Proterozoic deposits in the Tapajós Province, Brazil. Revista Brasileira de Geociências 29(2): 277-279.

JULIANI, C., R. H. CORREA-SILVA, L. V. S. MONTEIRO, J. S. BETTENCOURT \& C. M. D. NUNES, 2002. The Batalha AuGranite system e Tapajós Province, Amazonian Craton, Brazil: hydrothermal alteration and regional implication. Precambrian Research 119(1-4): 225-256.

JULIANI, C., R. O. RYE, C. M. D. NUNES, L. W. SNEE, R. H. C. SILVA, L. V. S. MONTEIRO, J. S. BETTENCOURT, R. NEUMANN \& A. ALCOVERNETO, 2005. Paleoproterozoic high-suldation mineralization in the Tapajós gold province, Amazonian Craton, Brazil: geology, mineralogy, alunite argon age, and stable isotope constraints. Chemical Geology 215(1-4): 95-125.

KLEIN, E. L., R. A. SANTOS, K. FUZIKAWA \& R. S. ANGÉLICA, 2001. Hydrothermal fluid evolution and structural control of the Guarim gold mineralization, Tapajós Province, Amazonian Craton, Brazil. Mineralium Deposita 36(2): 149-164.

KLEIN, E. L., L. T. ROSA-COSTA \& J. M. A. CARVALHO, 2004. Estudo de inclusões fluidas em veio de quartzo aurífero do prospecto Patinhas, Província Aurífera do Tapajós, Cráton Amazônico. Revista Brasileira de Geociências 34(1): 59-66.

KLEIN, E. L., M. E. ALMEIDA \& L. T. ROSA-COSTA, 2012. The 1.89-1.87 Ga Uatumã Silicic Large Igneous Province, northern South America. Large Igneous Provinces Commission. Disponível em: <http://www.largeigneousprovinces.org/12nov>. Acesso em: 22 abril 2015.

KONTAK, D. J., R. J. HORNE \& K. KYSER, 2011. An oxygen isotope study of two contrasting orogenic vein gold systems in the Meguma Terrane, Nova Scotia, Canada, with implications for fluid sources and genetic models. Mineralium Deposita 46(3): 289-304.

LAMARÃO, C. N., R. DALL'AGNOL, J. M. LAFON \& E. F. LIMA, 2002. Geology, geochemistry and $\mathrm{Pb}-\mathrm{Pb}$ zircon geochronology of the paleoproterozoic magmatism of Vila Riozinho, Tapajós Gold Province Amazonian Craton, Brazil. Precambrian Research 119(1-4): 189-223.

MAGELLAN MINERALS LTD., 2011 Resource estimate and technical report for the Cuiú-Cuiú Project Tapajos Region, North-Central Brazil: 1-134. Pincock, Allen \& Holt, Belo Horizonte. Disponível em: <http://www.magellanminerals.com/_resources/ tech_report_April_21_2011.pdf>. Acesso em: 19 maio 2015.
MATSUHISA, Y., J. R. GOLDSCHMIT \& R. N. CLAYTON, 1979. Oxygen isotope fractionation in the system quartz-albite-anorthitewater. Geochimica et Cosmochimica Acta 43(7):1131-1140.

MOURA, E. M., C. L. CHAVES \& F. G. R. PINHEIRO, 2014. Programa Geologia do Brasil-PGB: Cuiú-Cuiú. Folha SB-21X-C-IV. Estado do Pará. Carta Geológica. CPRM, Belém. (Mapa colorido, $100 \times 80 \mathrm{~cm}$, escala 1:100.000).

OHMOTO, H. \& R. O. RYE, 1979. Isotopes of sulfur and carbon. In: H. L. BARNES (Ed.): Geochemistry of hydrothermal ore deposits: 509-567. Jon Wiley \& Sons, New York.

O'NEIL, J. R. \& H. P. TAYLOR, 1969. Oxygen isotope equilibrium between muscovite and water. Journal of Geophysical Research 74(25): 6012-6022.

ROEDDER, E., 1984. Fluid inclusions: 1-646. Mineralogical Society of America (Reviews in Mineralogy, 12), Chantilly.

SANTIAGO, E. S. B., R. N. VILLAS \& R. C. OCAMPO, 2013. The Tocantinzinho gold deposit, Tapajós Province, State of Pará: host granite, hydrothermal alteration and mineral chemistry. Brazilian Journal of Geology 43(1): 185-208.

SANTOS, J. O. S., L. A. HARTMANN, H. E. GAUDETTE, D. I. GROVES, N. J. MCNAUGHTON \& I. R. FLECHER, 2000. New understanding of the Amazon Craton provinces, based on field work and radiogenic isotope data. Gondwana Research 3(4): 453-486.

SANTOS, J. O. S., D. I. GROVES, L. A. HARTMANN, M. A. MOURA \& N. J. MCNAUGHTON, 2001. Gold deposits of the Tapajós and Alta Floresta Domains, Tapajós-Parimaorogenic belt, Amazon Craton, Brazil. Mineralium Deposita 36(3): 278-299.

SANTOS, J. O. S., O. B. VAN BREEMEN, D. I. GROVES, L. A. HARTMANN, M. E. ALMEIDA, N. J. MCNAUGHTON \& I. R. FLETCHER, 2004. Timing and evolution of multiple Paleoproterozoic magmatic arcs in the Tapajós Domain, Amazon Craton: constraints from SHRIMP and TIMS zircon, baddeleyite and titanite $\mathrm{U}-\mathrm{Pb}$ geochronology. Precambrian Research 13: 73-109.

SANTOS, R. A. \& M. G. N. COUTINHO, 2008. Geologia estrutural. In: M. G. N. COUTINHO (Ed.): Província Mineral do Tapajós: geologia, metalogenia e mapa provisional para ouro em SIG: 97-135. CPRM, Rio de Janeiro.

SHARP, Z. D. \& D. L. KIRSCHNER, 1994. Quartz-calcite oxygen isotope thermometry: a calibration based on natural isotopic variations. Geochimica et Cosmochimica Acta 58(20): 4491-4501.

SHEPPARD, S. M. F., 1986. Characterization and isotopic variations in natural waters. In: J. W. VALLEY, H. P. TAYLOR JR. \& J. R. O'NEIL (Eds.): Stable isotopes in high temperature geological processes: 165-184. Mineralogical Society of America (Reviews in Mineralogy 16), Washington.

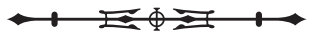


SILVA JÚNIOR, C. A. S., E. L. KLEIN, M. A. GALARZA, M. K. BORGES, J. D. S. QUEIROZ, R. F. S. ASSUNÇÃO, A. C. S. ARAÚJO \& D. J. MOORE, 2015. Zircon geochronology and Pb isotope systematics in sulfides: implications on the genesis of gold mineralization in the Cuiú-Cuiú goldfield, Tapajós Gold Province, Amazonian Craton, Brazil. Contribuições à Geologia da Amazônia 9.

VALLEY, J. W., N. KITCHEN, M. J. KOHN, C. R. NIENDORF \& M. J. SPICUZZA, 1995. UWG-2, a garnet standard for oxygen isotope ratios: strategies for high precision and accuracy with laser heating. Geochimica et Cosmochimica Acta 59(24): 5223-5231.

VAN DEN KERKHOF, F. \& R. THIERY, 1994. Phase transitions and density calculation in the $\mathrm{CO}_{2}-\mathrm{CH}_{4}-\mathrm{N}_{2}$ system. In: B. DEVIVO \& M. L. FREZZOTTI (Eds.): Fluid inclusions in minerals: methods and applications: 171-190. Blacksburg, Virginia.

VASQUEZ, M. L., E. L. KLEIN, M. L. E. S. QUADROS, R. B. C. BAHIA, A. SANTOS, P. S. F. RICCI, C. R. SACHETT, C. M. G. SILVA \& M. J. B. MACAMBIRA, 1999. Magmatismo Uatumã na Província Tapajós: novos dados geocronológicos. Anais do Simpósio de Geologia da Amazônia 6: 471-474.

VASQUEZ, M. L., E. L. KLEIN, M. J. B. MACAMBIRA, A. SANTOS, R. B. C. BAHIA, P. S. F. RICCI \& M. L. E. S. QUADROS, 2000. Geochronology of granitoids, mafic intrusion sand mineralizations of the Tapajós Gold Province - Amazonian Craton - Brazil. Abstracts of the International Geological Congress 31: 1 CD-ROM.

VASQUEZ, M. L., L. T. ROSA-COSTA, C. M. G. SILVA \& E. L. KLEIN, 2008. Compartimentação tectônica. In: M. L. VASQUEZ \& L. T. ROSA-COSTA (Orgs.): Geologia e recursos minerais do estado do Pará: Sistema de Informações Geográficas - SIG: texto explicativo dos mapas geológico e tectônico e de recursos minerais do Estado do Pará. Escala 1:1.000.000: 39-112. CPRM, Belém
VASQUEZ, M. L., C. L. ChaVES, E. M. MOURA, J. K. M. OLIVEIRA \& J. M. LAFON, 2013. Eventos magmáticos de 2020 - 1980 Ma nas Folhas São Domingos e Jardim do Ouro, porção leste do Domínio Tapajós. Anais do $13^{\circ}$ Simpósio de Geologia da Amazônia: 209-212.

VELOSO, A. S. R. \& M. D. SANTOS, 2013. Geologia, petrografia e geocronologia das rochas do depósito aurífero Ouro Roxo, Província Tapajós, Jacareacanga (PA), Brasil. Brazilian Journal of Geology 43(1): 22-36.

VILLAS, R. N. N., E. S. B. SANTIAGO \& M. P. CASTILHO, 2013. Contexto geológico, estudos isotópicos (C, $\mathrm{O}$ e Pb) e associação metálica do depósito aurífero Tocantinzinho, domínio Tapajós, Província Tapajós-Parima. Geociências USP. Série Científica 13(1): 119-138.

WENNER, D. B. \& H. P. TAYLOR JR., 1971. Temperatures of serpentinization of ultramafic rocks based on ${ }^{18} \mathrm{O} /{ }^{16} \mathrm{O}$ fractionation between coexisting serpentine and magnetite. Contributions to Mineralogy and Petrology 32(3): 165-185.

ZHENG, Y. F., 1993. Calculation of oxygen isotope fractionation in hydroxyl-bearing silicates. Earth and Planetary Science Letters 120(3-4): 247-263.

ZHENG, Y. F. \& J. HOEFS, 1993. Carbon and oxygen isotopic covariations in hydrothermal calcites: theoretical modeling on mixing processes and application to $\mathrm{Pb}-\mathrm{Zn}$ deposits in the Harz mountains, Germany. Mineralium Deposita 28(2): 79-89. 